\title{
3. PROVENANCE AND DISPERSAL PATTERNS, PLIOCENE-PLEISTOCENE SECTION AT SITE 645, BAFFIN BAY ${ }^{1}$
}

\author{
R. N. Hiscott, ${ }^{2}$ A. E. Aksu, ${ }^{2}$ and O. B. Nielsen ${ }^{3}$
}

\begin{abstract}
Cores from the upper 70 meters below seafloor (mbsf) (upper Pleistocene) at Ocean Drilling Program (ODP) Site 645 in Baffin Bay show dramatic meter-scale changes in color and mineralogy. Below this interval, mineralogical changes are more gradual to the top of the Miocene at about 550 mbsf. The Pliocene-Pleistocene section can be divided into five facies: Facies 1-massive, poorly sorted, gravel-bearing muds; Facies 2-gray silty clays and silty muds; Facies 3-laminated detricarbonate silty muds; Facies 4-silty sand and sandy silt; and Facies 5-poorly sorted muddy sands and silty muds. Facies 4 and 5 are restricted to the Pliocene section below depths of about 275 mbsf. The mineralogical/ color cycles in the upper $70 \mathrm{mbsf}$ are the result of alternations between Facies 2 and three lithotypes of Facies 1: lithotype A-tan-colored, carbonate-rich, gravel-bearing mud; lithotype B-weak, red-colored, gravel-bearing mud rich in sedimentary rock fragments; and lithotype C-gray, gravel-bearing mud. A fourth lithotype, D, is restricted to depths of 168-275 mbsf and is dark gray, carbonate-poor, gravel-bearing mud. We believe that all lithotypes of Facies 1 and the sand and gravel fractions of Facies 2 and 3 were deposited by ice rafting. Depositional processes for Facies 4 and 5 probably include ice rafting and bottom- and turbidity-current transport.

Data from petrographic analyses of light and heavy sand-sized grains and X-ray analyses of silt- and clay-size fractions suggest that tan-colored sediments (lithotype A of Facies 1; Facies 3) were derived mainly from Paleozoic carbonates of Ellesmere, Devon, and northern Baffin islands. Weak red sediments (lithotype B) contain significant red sedimentary clasts, reworked quartzarenite grains and clasts, and rounded colorless garnets, all derived from Proterozoic sequences of the Borden and Thule basins, and from minor Mesozoic red beds. Other sediments in the upper 335 mbsf at Site 645 contain detritus from a heterogeneous mixture of sources, including Precambrian shield terranes around Baffin Bay.

Sediments from 335 to 550 mbsf (Facies 5) are rich in friable sedimentary clasts and detrital micas and contain glauconite and, in a few samples, reworked diatoms. These components suggest derivation from poorly consolidated Mesozoic-Tertiary sediments in coastal outcrops and beneath the modern shelves of northeastern Baffin Island and western Greenland.

For the upper Pleistocene section (about 0-100 mbsf), marked mineralogical cyclicity is attributed to fluctuating glacial margins, calving rates, and iceberg melting rates, particularly around the northern end of Baffin Bay. Tan-colored, carbonate-rich units were derived at times of maximum advance of glaciers on Ellesmere and Devon islands, during relatively warm intervals induced by incursion of warm Atlantic surface water into the bay. At the beginning of these warmer episodes, most icebergs were contributed by glaciers near sea level around the Arctic channels, which resulted in deposition of weak red, ice-rafted units rich in Proterozoic sedimentary clasts.
\end{abstract}

\section{INTRODUCTION}

ODP Site 645 is situated in west-central Baffin Bay near the base of the Baffin Island slope (Fig. 1). Core descriptions and preliminary smear-slide analyses during drilling at the site indicated sharp stratigraphic changes in mineral composition in the Pliocene-Pleistocene section (top Pliocene = about $240 \mathrm{mbsf}$; top Miocene $=$ about $550 \mathrm{mbsf}$ ). Examples of these changes are as follows: (1) abundance of detrital dolostone and limestone varies widely on a scale of decimeters to meters (Fig. 2) in the upper $72 \mathrm{~m}$ (upper Pleistocene lithologic Subunit IA), (2) weak red $(2.5 Y R 4 / 2)$ units with grains containing iron oxide occur at several levels over the same interval (Fig. 2), (3) below a depth of about 170-180 mbsf, shipboard analyses indicated that carbonate content decreases dramatically from a range of $20 \%$ to $40 \%$ to a range of $5 \%$ to $20 \%$, and (4) below $425 \mathrm{msbf}$ carbonate content is only a small percentage.

We interpreted most of the Pliocene-Pleistocene section at Site 645 as the product of ice rafting, because of the lack of physical structures, poor sorting, and ubiquitous outsized peb-

\footnotetext{
${ }^{1}$ Srivastava, S. P., Arthur, M., Clement, B., et al., 1989. Proc. ODP, Sci. Re sults, 105: College Station, TX (Ocean Drilling Program).

2 Department of Earth Sciences, Memorial University of Newfoundland, St. John's, Newfoundland A1B 3X5, Canada.

3 Department of Geology, Aarhus University, DK-8000 Aarhus C, Denmark.
}

bles and cobbles. However, similar features can be found in debris-flow deposits (debrites). Following the drilling of Leg 105 two of us (RNH and AEA) acquired high-resolution, singlechannel seismic records near Site 645 (Hudson cruise 87033) that indicate (1) major upslope erosion to depths of several hundred meters, and (2) the presence of many mound-shaped, acoustically transparent lenses in the lower slope near Site 645, but mostly just upslope from the site. We provisionally interpret these lenses as debrites. Coring of one lens recovered homogeneous, dark gray, pebbly mud unlike the distinctly colored, relatively thin units that form the lithologic cycles observed in cores in the upper $50 \mathrm{mbsf}$ at Site 645 . We consider it unlikely that each mineralogically distinct bed of tan and red pebbly mud at Site 645 was emplaced by debris flow or related processes tapping a compositionally restricted source. The cored debrite (Hudson cruise 87033) is instead heterolithic, as would be expected for debris generated by upslope failure and mixing of a stratigraphic package of considerable thickness. We plan to core more of these debrite lenses to determine if this heterolithic character is the rule.

Preliminary assessment of the new seismic data suggest only one major debrite lens at Site 645, at depths of 40-70 mbsf (see also Srivastava, Arthur, et al., 1987, p. 146). Thus, the weight of available evidence does not support debris flow as the process responsible for deposition of the bulk of the gravel-bearing section at Site 645 . We believe instead that lithologic variations (Fig. 2) reflect alternation of source areas for icebergs during 


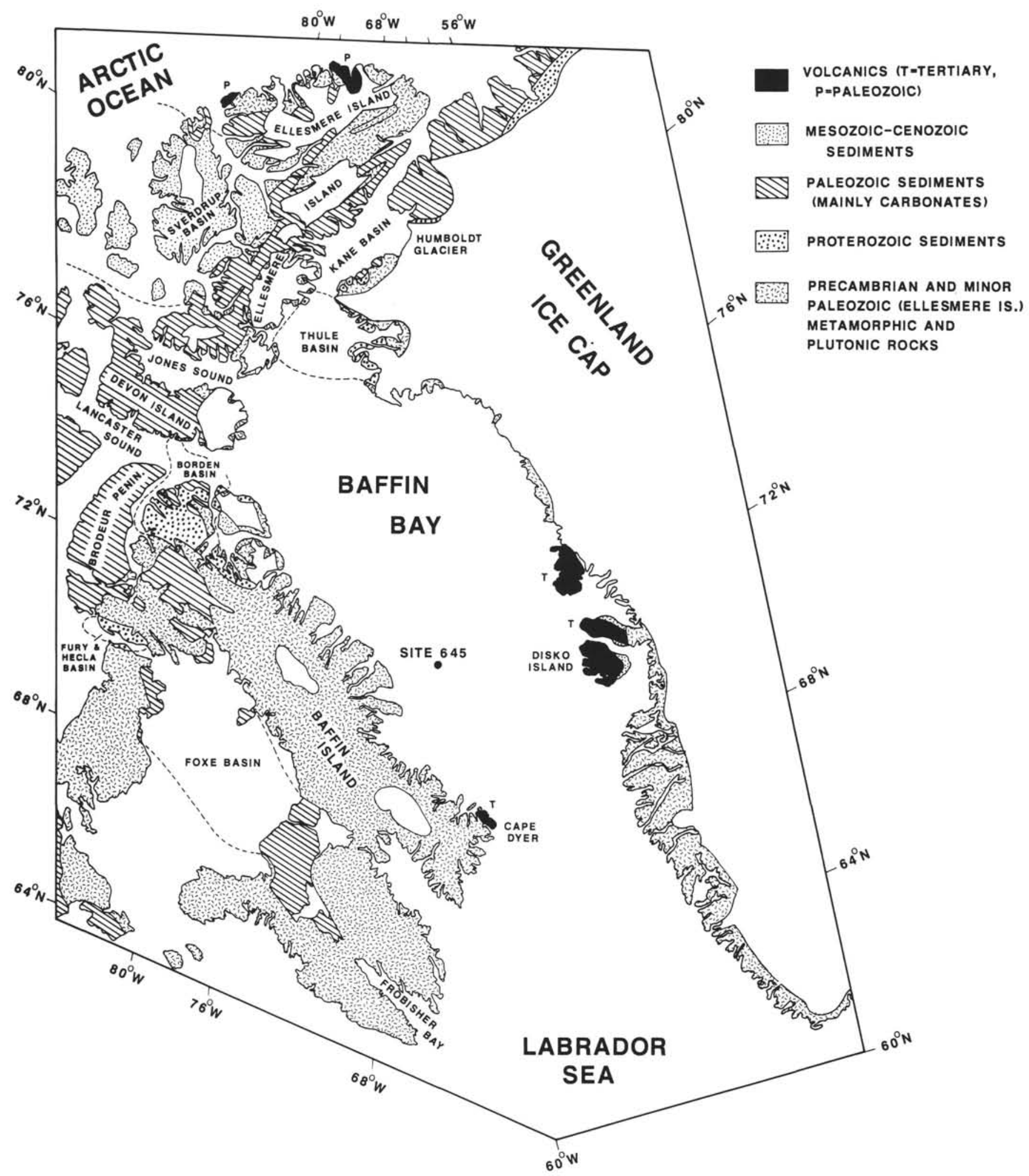

Figure 1. Simplified geological map of the landmasses around Baffin Bay, compiled from Geol. Surv. of Canada maps 1250A and 1253A (Douglas, 1970), Escher (1970), Jackson and Iannelli (1981), and Dawes et al. (1982). Water bodies and ice sheets are unpatterned. Confusion of water and ice is only possible southeast of Foxe Basin, where two lakes occur at the margin of the Paleozoic outcrop. Important sedimentary basins are outlined (dashes) and named. 

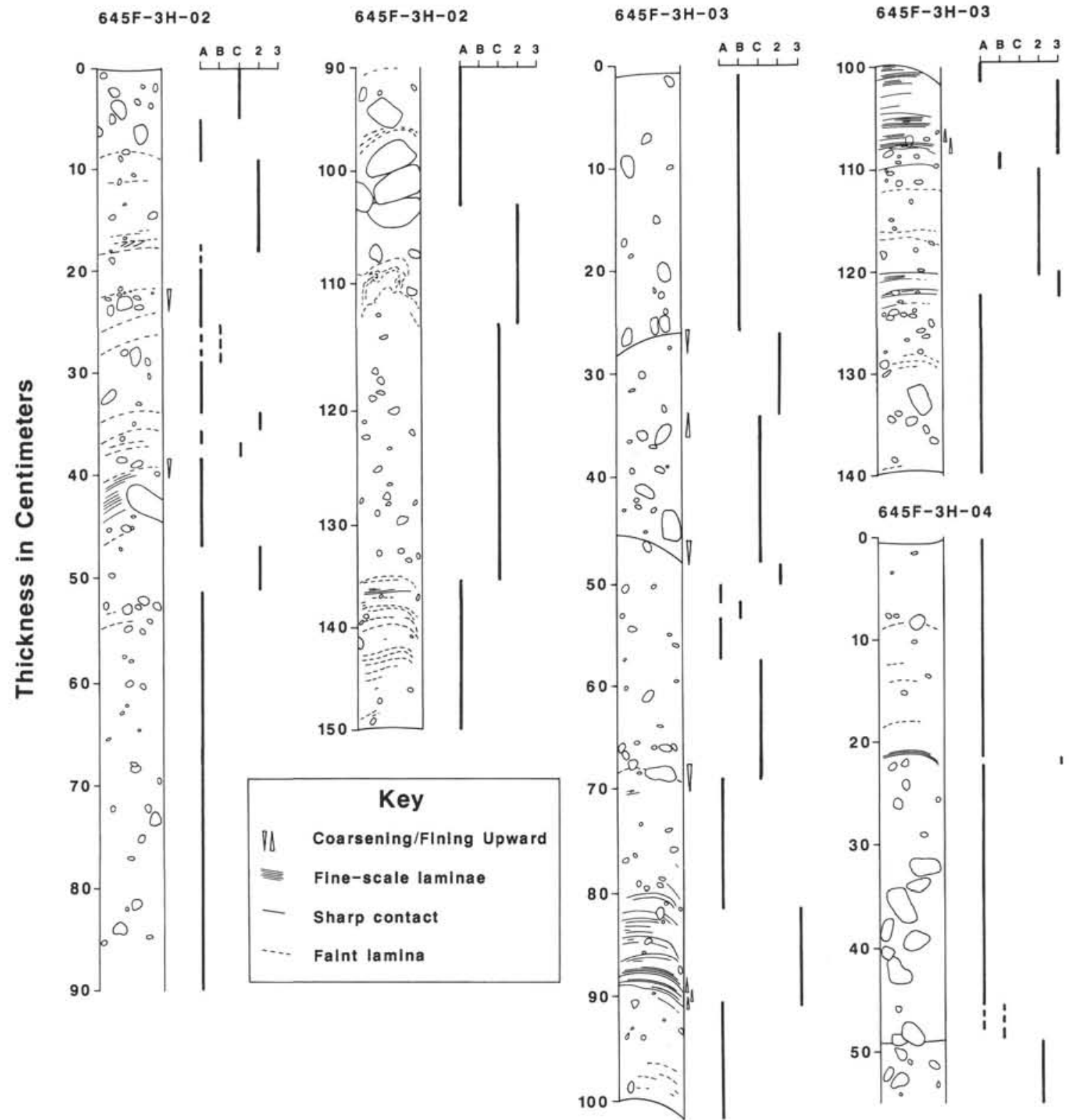

Figure 2. Internal structures, outline of clasts larger than about $0.5 \mathrm{~cm}$, bedding contacts, and occurrence of Facies 1 (lithotypes A, B, and C), Facies 2, and Facies 3 in three sections of Core 105-645F-3H. The lithotypes and facies are defined later in the text, but are essentially as follows: lithotype $\mathrm{A}=\tan$-colored (carbonate-rich) gravel-bearing mud; lithotype $\mathrm{B}=$ reddish gravel-bearing mud; lithotype $\mathrm{C}=$ gray/brown gravel-bearing mud; Facies 2 = gray silty clay and silty mud; Facies $3=$ laminated detricarbonate silty mud (turbidites). Facies and internal characteristics were recognized from whole-core color transparencies and a complete set of X-radiographs.

the course of the late Tertiary and Quaternary glaciations. We infer that the predominant transport process is ice rafting.

This investigation is an attempt to identify the source rocks for the main facies at Site 645, to a depth of about 550 mbsf, using the following techniques: (1) petrographic examination of thin sections cut from light mineral grain mounts, (2) examination of heavy mineral mounts, and (3) partial X-ray diffraction analysis of the 2-63 and $<2 \mu \mathrm{m}$ fractions from selected facies in the upper $170 \mathrm{~m}$. At greater depths, the data of Thiebault et al. (this volume) summarize mineralogy of the clay-size fraction.

The semi-enclosed nature of Baffin Bay allows us to assume that most detrital material was derived from west and north Greenland, and from the Canadian Arctic Islands adjacent to the bay. Bedrock geology of this area is summarized before we present new data so that the reader will be familiar with the characteristics of available source areas (see also, Korstgärd and Nielsen, this volume). However, one must remember that much of Greenland is blanketed by a modern icecap that conceals possible source areas for Baffin Bay sediments.

\section{GEOLOGY OF THE SURROUNDING LAND}

Most parts of western Greenland and eastern Baffin Island are underlain by Precambrian granitic gneisses that at the northern end of Baffin Bay are generally hypersthene-bearing and associated with garnet schists (Frisch and Dawes, 1982). The Precambrian shield also contains highly metamorphosed sediments, including marbles with diopside, forsterite, wollastonite, and spinel (Frisch and Dawes, 1982); metavolcanics; and intrusive rocks containing orthopyroxenes and hornblende. The metavolcanics are generally amphibolites, which in many cases are gar- 
netiferous (Dawes and Frisch, 1981). On the Greenland shelf, the Precambrian crystalline basement extends seaward of the coastline before being buried by younger, principally Mesozoic and Tertiary sequences (Brett and Zarudzki, 1979). On the Baffin Island shelf, Precambrian crystalline rocks are locally exposed on the walls of submarine channels (MacLean and Falconer, 1979).

Proterozoic sedimentary rocks and associated volcanics unconformably overlie the crystalline shield on northwest Baffin, Ellesmere, Somerset, and Bylot islands, as well as in northwest Greenland (Thorsteinsson and Tozer, 1960; Jackson and Iannelli, 1981; Dawes et al., 1982). The Thule Group of the Thule Basin (Fig. 1) consists of red- to white-colored siliciclastic rocks interbedded with minor shales, carbonates (stromatolitic limestones and dolostones), and volcanics (Dawes et al., 1982). The lower Thule Group, both in northwest Greenland and on the adjacent coast of Ellesmere Island, is capped by about $1500 \mathrm{~m}$ of thick-bedded quartzarenites and quartz-pebble conglomerates, ferruginous sandstones, and minor drab-colored shales (Dawes et al., 1982).

On northern Baffin Island, several kilometers of Proterozoic quartzarenites as well as thick units of red clastic rocks, dolostones, and limestones are present in (1) the Borden Basin and (2) the Fury and Hecla Basin (Jackson and Iannelli, 1981). These successions are broadly correlative in age with the strata in the Thule Basin.

On the coast of northwestern and northern Greenland and on Ellesmere and Devon islands about $100 \mathrm{~km}$ away from the mouths of arctic channels entering Baffin Bay (Fig. 1), the crystalline basement is overlain by Cambrian to Devonian limestones and dolostones, interbedded with calcareous shales and red-colored siliciclastic rocks (Kerr, 1976). Similar rocks also crop out on northwestern Baffin and Bylot islands; on Melville, Brodeur, and Borden peninsulas of Baffin Island; and beneath the lowlands of western Baffin Island. Paleozoic rocks (mainly Ordovician limestones) also occur on the southeastern Baffin Island shelf (MacLean et al., 1977; MacLean and Falconer, 1979).

Mesozoic and Cenozoic rocks crop out on Ellesmere Island, northern Baffin Island and adjacent southwestern Bylot Island (Miall et al., 1980; West et al., 1981; Miall, 1986), on the central western coast of Greenland (Henderson et al., 1981), and locally around Cape Dyer on Baffin Island. At the latter two localities, the sediments are associated with Tertiary volcanics. The sedimentary rocks are predominantly marine and fluviatile sandstones and siltstones, interbedded with coal-bearing shales and red hematite-stained sandstones.

On the Greenland shelf, the Tertiary sediments extend seaward to about the $300-400 \mathrm{~m}$ isobath. In shallower water depths, these rocks are eroded with the erosional surface overlain by flat-lying Quaternary sediments (Brett and Zarudzki, 1979). On the Baffin Island shelf, bevelled Cretaceous and Tertiary sedimentary sequences lie immediately beneath a Quaternary veneer over large areas and crop out locally along the margins of transverse troughs that cut the shelf (MacLean et al., 1981). Samples recovered from these trough walls are predominantly sandstones and siltstones.

Tertiary basalts are widespread in the Disko Island area and extend from $68^{\circ} \mathrm{N}$ to about $73^{\circ} \mathrm{N}$ latitudes; similar volcanic rocks occur locally around Cape Dyer (Clarke and Upton 1971; Henderson, 1973). South of Disko Island, boreholes drilled for hydrocarbon exploration penetrated shallow-marine siliciclastic sediments of Late Cretaceous and Paleogene age to depths of about $3.5 \mathrm{~km}$ (Rolle, 1985).

\section{FACIES AT SITE 645}

Five facies account for most of the Pliocene-Pleistocene section at Site 645. One facies is subdivided into four "lithotypes" to recognize important compositional differences. These compositional differences are strongly reflected in the color of the sediments (Fig. 2).

\section{Facies 1, Massive, Poorly Sorted, Gravel-Bearing Units}

The sediments assigned to this facies were subdivided on board ship into muddy sands, silty and clayey muds, silty clays, and clayey silts (Fig. 3). All sediments are characterized by scattered large clasts up to gravel size, lack of clear lamination or stratification, and poor sorting. In ancient sequences, all these sediments would be called pebbly mudstones. Several grain-size analyses of this facies (Fig. 4) failed to substantiate shipboard estimates of sand contents high enough to assign any of the samples to the muddy sand category (see also Thiebault et al., this volume). Instead, the major components of the grain-size distribution are silt and clay.

\section{Lithotype $A$}

This lithotype is $\tan$ in color (10 YR $4 / 2$ to $6 / 2$ ) owing to abundant detrital carbonate grains of all sizes. X-radiographs indicate rare, centimeter-thick, laminated and cross-laminated horizons that may be genetically related to Facies 3 . In piston cores collected near the site (Aksu, 1981), microcrystalline limestone and dolostone are the dominant gravel components (up to $80 \%$ ). More than $75 \%$ of these clasts exhibit well-polished surfaces with distinct glacial striae, whereas the rest are angular and have freshly broken surfaces. Undifferentiated granitic/ gneissic rocks are second in abundance, and next are smaller quantities of metamorphic and siliciclastic rocks. Using data from piston cores throughout Baffin Bay, Aksu (1981) showed that the carbonate clasts in this lithotype decrease in abundance eastward and southward to $<20 \%$, which parallels the overall thinning of lithotype $\mathrm{A}$ in the piston cores. Metamorphic and granitic clasts become more abundant as carbonate clasts decline in importance (Aksu and Piper, 1987). Piston-core samples of this lithotype contain variable amounts of reworked microfossils: $55 \%$ of the samples contained Eocene flora; $35 \%$ Upper Cretaceous flora; and the remaining $10 \%$ contained chitinoza of Ordovician-Silurian age (Aksu, 1981).

\section{Lithotype $B$}

This lithotype is characterized by its distinct red color $(2.5$ YR 4/2). It tends to occur immediately below a unit of lithotype $\mathrm{A}$ and above dark gray silty clays and clayey silts (Facies 2). Available samples of this lithotype were limited, thus some details about pebble composition will be taken from Aksu's work (1981) for our later analysis. In nearby piston cores, pebbles in this lithotype consist mainly of red- to white-colored sandstones and siltstones associated with varying proportions of limestones and dolostones. Present in lesser amounts in this lithotype, metamorphic and granitic clasts increase in importance toward the southern end of Baffin Bay. Quartz sand grains commonly are well rounded. Based on piston core data, about $80 \%$ of lithotype B samples contain Upper Cretaceous dinoflagellates; about $60 \%$ of these same samples also contain Eocene, Paleocene, and Ordovician-Silurian flora.

\section{Lithotype $C$}

This lithotype includes all representatives of Facies 1 not assigned to lithotypes A and B, to the base of lithologic Unit I (168 mbsf), and thus volumetrically dominates lithotypes A and $\mathrm{B}$ at the site. Colors are various shades of gray and brown.

\section{Lithotype D}

This lithotype has a stratigraphic range that coincides with lithologic Unit II (168-335 mbsf). Shipboard analyses indicated that bulk carbonate content decreases at the top of lithologic 


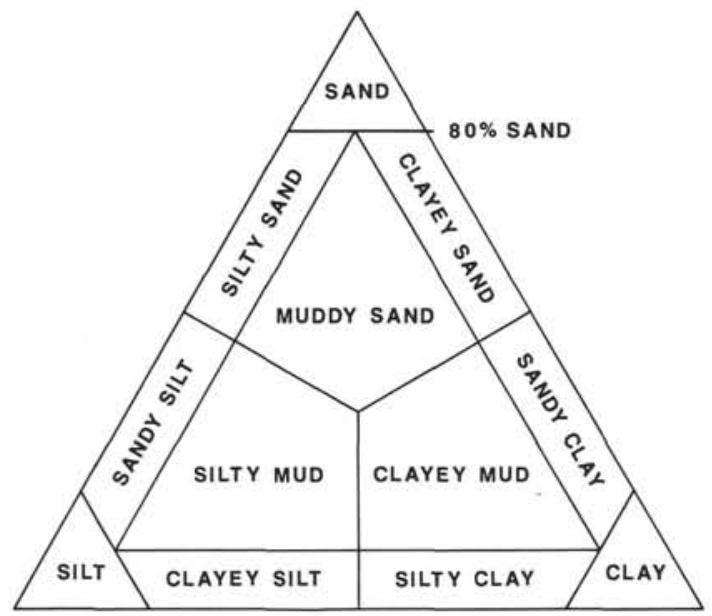

Figure 3. Ternary classification of terrigenous sediments used during Leg 105 and in this paper.

Unit II, but the only visual change is a darkening of color to dark gray and dark greenish-gray (5Y $4 / 1$ to 5 GY 4/1). Black iron sulfide smears characterize the core in this lithotype, and burrowing is a common feature.

\section{Facies 2, Gray Silty Clays and Silty Muds}

This facies consists of gray to olive gray (5Y 6/1 to 5/2) silty clay and silty mud with isolated, floating, gravel-sized clasts. Cores and X-radiographs reveal no primary lamination. In cases where this facies overlies lithotype A of Facies 1, the color difference allowed us to recognize large burrows that began in $\mathrm{Fa}-$ cies 2 muds. We suspect that much of this facies contains burrows.

$\mathrm{X}$-radiographs indicate thin to very thin beds $(<10 \mathrm{~cm})$ of Facies 1 gravel-bearing sediment within units of Facies 2-type. Facies 2 also is associated with thinly graded and laminated couplets that characterize Facies 3 . Both these facies are essentially restricted to lithologic Unit I (0-168 mbsf).

\section{Facies 3, Laminated Detricarbonate Silty Muds}

This facies consists of about centimeter-thick, sharp-based, graded, laminated to cross-laminated, tan-colored silty muds. Hiscott et al. (this volume) describe and interpret these laminated units as turbidites. Ice-rafted gravel is rare, and if present is concentrated in the "pelagic" $T_{e}$ division of the turbidites (Cremer, this volume).

\section{Facies 4, Silty Sand and Sandy Silt}

This facies is present only over a 5.5-m interval at the base of lithologic Unit II and consists of apparently structureless silty sand and locally sandy silt. Shipboard microscopy suggested up to $10 \%$ heavy minerals in some parts of this sand unit.

\section{Facies 5, Poorly Sorted Muddy Sands and Silty Muds}

The upper part of lithologic Unit IIIA, to the approximate Pliocene/Miocene boundary at a depth of $550 \mathrm{~m}$, is characterized by poorly sorted muddy sands and silty muds with scattered coarse sand and granule clasts. The largest clasts are invariably sedimentary in origin, mainly black shale or siltstone. Most of this facies is structureless, but there are several sharpbased, meter-thick, poorly graded to ungraded units that Hiscott et al. (this volume) interpret as possible deposits of highconcentration turbidity currents or sandy debris flows. We believe that meter-scale, gradual coarsening/fining/coarsening cycles reflect temporal variations in the strengths of bottom currents (Thiebault et al., this volume).

\section{METHODS}

For petrographic studies, 46 samples were selected in such a way as to provide representative material for all facies over the entire PliocenePleistocene section (Fig. 5). Mineralogical variation is greatest in lithologic Subunit IA (0-72 mbsf); thus, sampling was biased toward this interval. Grains larger than $2 \mathrm{~mm}$ (except in Facies 5) were separated and examined by Nielsen as part of a broader study on provenance of gravel at all Leg 105 sites (Korstgaard and Neilsen, this volume); these data for granule and gravel composition are sparse compared to piston-core results of Aksu and Piper (1987) and are not duplicated here.

A split of the $0.063-2-\mathrm{mm}$ fraction (sand range) was separated into heavy and light fractions using nontoxic heavy liquid sodium polytungstate (Callahan, 1987) diluted with water to a specific gravity of 2.89 . The sample was centrifuged for $10 \mathrm{~min}$ at $4000 \mathrm{rpm}$ to speed separation. Despite this treatment, examination of heavy separates prepared during initial runs indicated contamination to variable degrees by quartz, feldspar, and carbonate grains. Remaining samples (about one-third) were separated in warm polytungstate (less viscous) with longer settling times, which provided a much better separation.

Unfortunately, samples cannot be re-run with this heavy liquid because minute quantities of crystalline polytungstate adhere to the grains and increase their density. The contamination by light minerals did not affect heavy mineral determinations, except for minor quartzlike species such as topaz and apatite. Apatite probably was underestimated in early counts, whereas samples prepared with warm liquid had more reliable apatite percentages on the order of $5 \%$.

A split of the light fraction was mounted in epoxy resin, and a thin section was prepared without cover slip. Point counts ( 250 mineral points) were undertaken using the variables quartz, feldspar, siliciclastic rock fragments (sandstones, siltstones, shales), carbonate (plus chert and mixed carbonate-siliciclastic grains), volcanic rock fragments, schist and slate fragments, oxides (plus minor glauconite), and heavy minerals plus micas. Heavy minerals in these "light" mounts are a product of the difficulty experienced with the sodium polytungstate liquid as a separating agent.

A second count (100 mineral points) was undertaken to estimate the importance of recycled quartz grains for grains coarser than $0.125 \mathrm{~mm}$. Categories were (1) grains with attached overgrowths of quartz or attached carbonate cements, (2) grains with roundness, $\rho$, in excess of 4 (round and very round on Folk's scale, 1955), (3) grains with roundness, $\rho$, less than 4 (very angular, angular, subangular, and subround grains), and (4) quartz crystals within igneous or coarsely crystalline metamorphic clasts. If a grain had clearly been broken from a round or very round particle, then it was counted in the second category $(\rho>4)$, despite its current angularity. Such cases were rare.

Most thin sections that contained more than about $5 \%$ siliciclastic rock fragments were recounted for types of these rock fragments: red shales, other shales, red sandstones and siltstones, other sandstones and siltstones, quartzarenite grains, and siltstone or sandstone grains containing at least one glauconite peloid. As a final step, cover slips were removed and the thin sections were stained with Alizarin Red S to distinguish calcite from dolomite. The relative proportions of limestone and dolostone clasts were then estimated by viewing a large area of the grain mount.

Heavy-mineral separates were split to exclude the largest grains (i.e., approximately $>0.25 \mathrm{~mm}$ ) and then mounted on glass slides in a pool of epoxy resin or Caedex $(R I=1.55)$ large enough to just cover the grains. We found that Caedex was superior because the epoxy resin became strained while hardening around the grains, which led to anisotropic behavior. Only nonmicaceous translucent grains were counted under the microscope using a line method of counting (Galehouse, 1969). Light grains that contaminated many slides were ignored, although in the process some true heavy minerals of similar appearance to quartz (e.g., apatite) may have been missed. Only a maximum of a few grains in each count of 100 were so altered or murky that they could not be identified. These grains were ignored. All carbonate grains also were ignored, even though dolomite may have a specific gravity great enough to qualify as a heavy mineral.

The heavy minerals were identified solely on the basis of optical properties outlined in standard texts, such as Milner (1962), and by comparison with standard mounts of known minerals. We were very confident of identification for the most common species (hornblende, garnets, clinopyroxenes, hypersthene, enstatite, and epidote) and for minerals with unique properties (zircon, tourmaline, monazite, kyanite, apatite). We were less confident of our identification of some minor 
R. N. HISCOTT, A. E. AKSU, O. B. NIELSEN
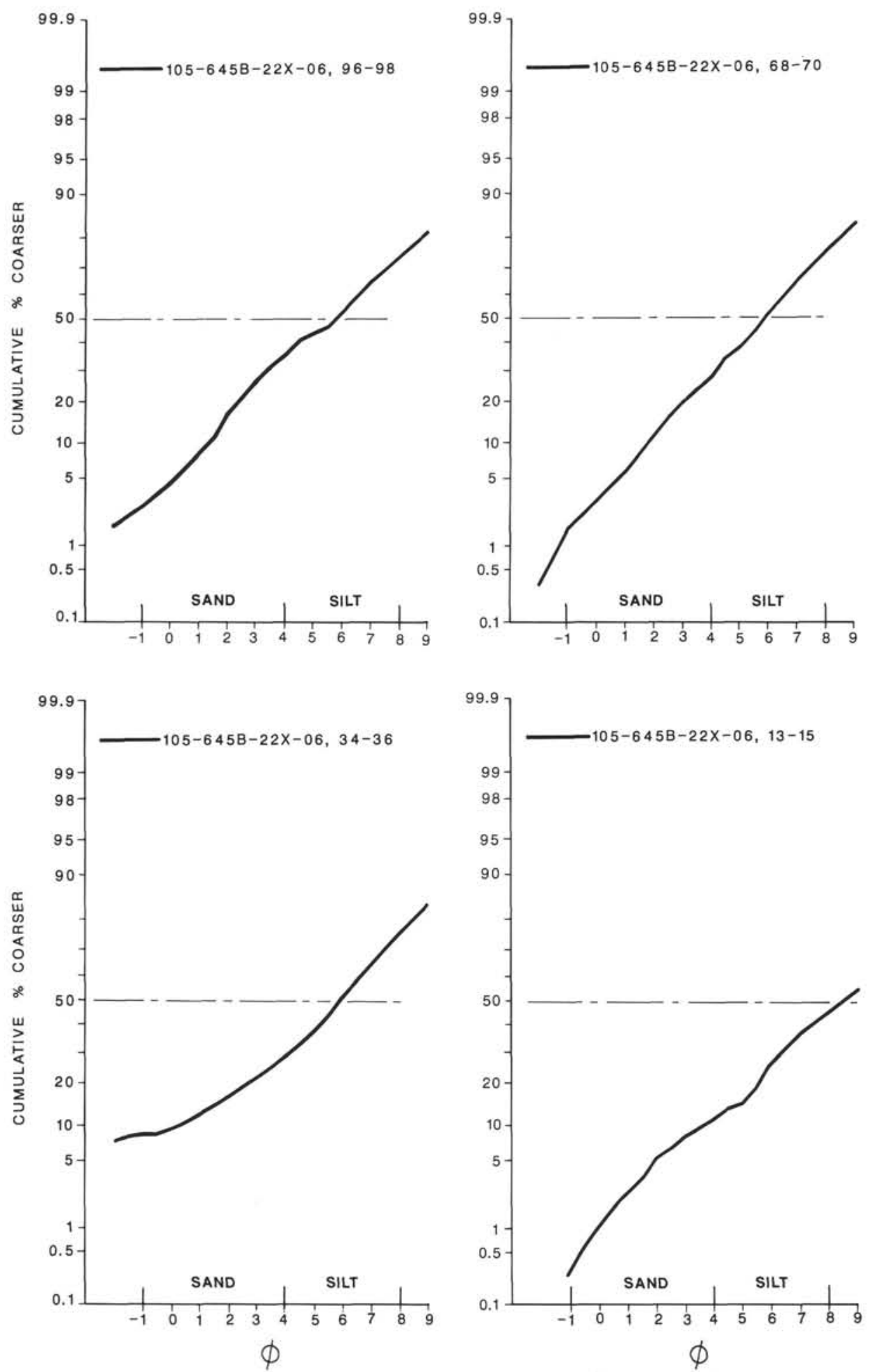

Figure 4. Representative grain-size profiles for Facies 1 gravel-bearing units. The small ODP samples exclude most pebbles and cobbles (e.g., Fig. 2). Analyses were performed with sieves and pipette. Note that sand percentage ranges from $10 \%-30 \%$ only.

minerals (some epidote group minerals, some olivine, topaz, spinel, sphene, fluorite, and idocrase).

All point counts for light minerals and line counts for heavy minerals were undertaken by Hiscott to allow an independent comparison with results obtained from piston-core samples by Aksu (1981).

Separate splits of silt-size $(2-63 \mu \mathrm{m})$ and clay-size minerals $(<2 \mu \mathrm{m})$ from several of the same samples that were examined petrographically were analyzed by X-ray diffraction at Aarhus University, Denmark. Only samples from lithologic Unit I ( $0-168 \mathrm{mbsf})$ were analyzed because lithologic variability was on such a fine scale in this unit that the general results of Thiebault et al. (this volume) cannot be integrated with our facies- and lithotype-specific analysis. Analysis of the silt fraction was restricted to the following categories: quartz, alkali feldspar, plagioclase, calcite, dolomite, pyrite, and undifferentiated clay minerals. The clay- 


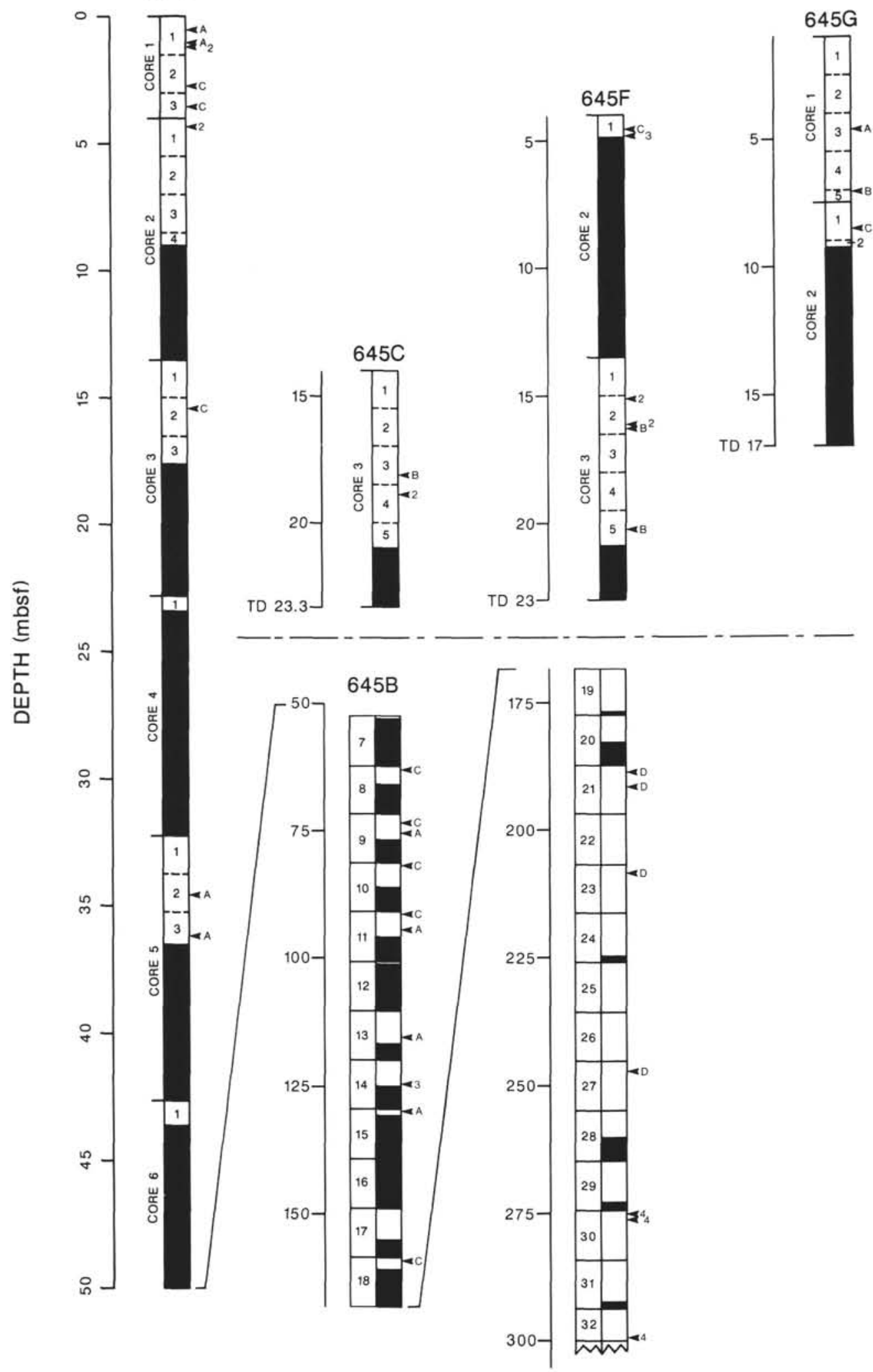

Figure 5. Summary of cored intervals at Site 645 to a depth of $300 \mathrm{mbsf}$. Recovered sediment is shown in white, with sections numbered above 50 mbsf. Holes $645 \mathrm{C}, 645 \mathrm{~F}, 645 \mathrm{G}$, and the upper $25 \mathrm{~m}$ of Hole $645 \mathrm{~B}$ are correlated as set out in Srivastava, Arthur, et al. (1987). Below a depth of $50 \mathrm{mbsf}$ in Hole 645B, the scale changes on this diagram to condense the deeper section. All samples from Facies 1, 2, 3, and all but one from Facies 4 are indicated with arrows. Facies 1 samples are subdivided into lithotypes A, B, C, and D. The remaining Facies 4 sample and all Facies 5 samples come from Holes 645D and 645E and range from 275 to $540 \mathrm{mbsf}$. 
size fraction $(<2 \mu \mathrm{m})$ was analyzed for the four major clay-mineral species (smectite, illite, kaolinite, and chlorite), as well as the set of minerals listed above for the silt-fraction analysis.

The silt- and clay-size fractions were separated by repeated decanting of a suspension of $<63-\mu \mathrm{m}$ sediment in distilled water. The silt fraction was dried and weighed, a split was mounted in an aluminum sample holder with random orientation of mineral grains, and then this preparation was scanned with a Philips PW 1710 diffractometer $\left(\mathrm{Cu} \mathrm{K}_{\alpha}\right.$ radiation, graphite monochromator, automatic divergence slit) over the $2 \theta$ range $2-65^{\circ}$ at a speed of $1.8^{\circ} 2 \theta / \mathrm{min}$. Minerals were identified by the distance between crystal planes. Where three or more characteristic $d$ spacings matched values on ASTM cards, we considered identification as correct. To obtain semiquantitative data, the areas of characteristic peaks for each mineral were weighted by factors modified somewhat from Cook et al. (1975) to give the most accurate results with the Aarhus University diffractometer. For the silt fraction, the peaks and weighting factors are $0.426 \eta \mathrm{m}$ quartz peak, $\times 0.25 ; 0.325 \eta \mathrm{m}$ alkali feldspar peak, $\times 0.1 ; 0.320 \eta \mathrm{m}$ plagioclase peak, $\times 0.1 ; 0.303 \eta \mathrm{m}$ calcite peak, $\times 0.1 ; 0.288 \eta \mathrm{m}$ dolomite peak, $\times 0.1 ; 0.271 \eta \mathrm{m}$ pyrite peak, $\times 0.08$; $0.446 \eta \mathrm{m}$ total clay-minerals peak, $\times 1.0$.

From the clay fractions, oriented smear slides on glass plates were analyzed using the diffractometer settings outlined above after (1) air drying, (2) glycolation for $24 \mathrm{hr}$ at $60^{\circ} \mathrm{C}$, and (3) heating at $500-550^{\circ} \mathrm{C}$ for $2 \mathrm{hr}$. Clay minerals were identified using procedures of Brindley and Brown (1980). Semiquantitative data were obtained by applying weighting factors to the areas of characteristic peaks measured on the glycolated mount (see Johns et al., 1954; Schultz, 1964; Biscaye, 1965). These peaks and weighting factors are (1) $1.7 \eta \mathrm{m}$ smectite peak, $\times 1.0,(2)$ $1.0 \eta \mathrm{m}$ illite peak, $\times 3.0$, and (3) $0.7 \eta \mathrm{m}$ kaolinite plus chlorite peak, $\times$ 1.15 . Relative chlorite abundance was obtained by multiplying the combined kaolinite + chlorite peak area by (1) the height of the $1.4-\eta \mathrm{m}$ peak on the heat-treated run and then dividing by (2) 1.5 times the height of the 0.7- $\eta \mathrm{m}$ peak on the air-dried run (Schultz, 1964). The kaolinite abundance then was corrected for this chlorite contribution to the peak area on the glycolated mount.

The nonclay minerals of the clay-size fractions were quantified using correction factors slightly different from those of Cook et al. (1975). Specifically, peaks and their associated weighting factors are (1) 0.426 $\eta \mathrm{m}$ quartz peak, $\times 1.0,(2) 0.325 \eta \mathrm{m}$ alkali feldspar peak, $\times 0.4,(3)$ $0.320 \eta \mathrm{m}$ plagioclase peak, $\times 0.4$, (4) $0.303 \eta \mathrm{m}$ calcite peak, $\times 0.25$, (4) $0.288 \eta \mathrm{m}$ dolomite peak, $\times 0.25$, and (6) $0.271 \eta \mathrm{m}$ pyrite peak, $\times$ 0.66 .

\section{SAND COMPOSITION-LIGHT FRACTION}

Major components, quartz varieties, and the relative proportion of dolomite in the carbonate grain suite are presented in Table 1. A breakdown of sedimentary rock fragments (SRF) is given in Table 2 for the few samples that were suitable for a recount of the SRF component. Before briefly outlining the main compositional attributes of each facies, we will give a few general comments about the characteristics of some components.

Carbonate clasts are predominantly finely crystalline dolostone, with no preservation of primary limestone fabrics. In lithologic Unit I (Facies 1; lithotypes A, B, and C; Facies 2; and Facies 3), subordinate limestone clasts occur, and some contain fossil fragments (Plate 1, Fig. 1). However, most limestone clasts are micritic. In addition to clasts formed exclusively of carbonate minerals, a significant amount of mixed carbonate-siliciclastic siltstones and fine sandstones can be seen. In cases where the carbonate component was dominant, these clasts were counted as carbonate grains, a reasonable procedure because these clasts are invariably associated with other silicate-poor carbonate grains. Chert is relatively rare in all samples and is present only in carbonate-rich samples. For this reason, chert is grouped with carbonates in Table 1.

The quartz population is characterized in all facies by variable amounts of round or very round grains and grains with overgrowths around round cores (Plate 1, Figs. 2, 3). In many samples, these are accompanied by quartzarenite clasts (Plate 1, Fig. 4) that are generally quartz cemented, but that also may be calcite cemented. Quartz grains having overgrowths or high round- ness values are most common in lithotypes $\mathrm{A}$ and $\mathrm{B}$ and in $\mathrm{Fa}$ cies 5. A crude estimate of the proportion of quartz that came from a quartzarenite source can be obtained by summing "grains with overgrowths" and "grains with roundness, $\rho$, greater than 4." Within quartzarenite clasts, however, quartz grains often have $\rho<4$, so that the importance of a quartzarenite source is probably underestimated using this conservative procedure.

Volcanic fragments are generally rare, but may form up to $2 \%$ of the grains in some samples (Table 1). These fragments generally have basaltic (lathwork or microlithic) textures (Plate 1 , Figs. 5, 6), but some fragments of chloritic devitrified glass also were encountered. The basaltic grains contain plagioclase laths and, in some cases, pyroxene crystals.

Unequivocal metamorphic rock fragments (schist or slate) are rare, probably because the high-grade gneisses on surrounding landmasses are coarsely crystalline, resulting in monomineralic or "igneous"-looking grains. However, some sandstone fragments may have been derived from metasediments, because they are characterized by coarse, sericite micas and chlorite that in some cases have a crude alignment (Plate 2, Fig. 1). Except for Facies 5 and a few samples from lithotype D and Facies 4, noncarbonate sedimentary rock fragments are a variety of shales, silty shales, and siltstones or fine-grained sandstones. These grains are either essentially quartz-feldspar-illite/sericite particles, or are pale to deep red owing to the presence of hematite grain coatings and cements (Plate 2, Fig. 2). Some samples contain grains that are almost entirely iron oxide (hematite), but some of these grains contain scattered angular silicate grains and clearly have a sedimentary origin. We found it difficult to distinguish between red shales and "oxide" particles (Tables 1 and 2) and in some cases made arbitrary distinctions. The highest concentration of red sedimentary rock fragments is in lithotype B, where quartz grains also are commonly characterized by red hematite rims.

Throughout Facies 5, and in a few samples from lithotype 1D and Facies 4 (e.g., Samples 105-645B-27X-02, 48-53 cm, and $105-645 \mathrm{D}-2 \mathrm{R}-04,36-41 \mathrm{~cm}$ ), the SRF component is composed of dark brown, poorly lithified mudstone and silty mudstone clasts (Plate 2, Fig. 3), essentially the only clast type in Facies 5 . These clasts are in various states of disintegration, which contributes very fine sand and silt particles of quartz, feldspar, hornblende, and mica to the sediment. In four samples (the two listed above and Samples 105-645D-10R-02, 20-25 cm, and 105645E-9R-06, 59-64 cm), these mudstone clasts are rich in diatoms, spicules, and minor radiolarians. Unfortunately, the assemblage consists of long-ranging species of Coscinodiscus and Melosira (J. Baldauf, pers. comm., 1987) that precludes our dating the probable Cretaceous or Paleogene source.

Glauconite peloids are rare, although we noted examples in lithotype A, Facies 2, and in Facies 5 (widely, although at low abundance in this facies). An exception is Sample 105-645C-3H04, 39-41 cm (Facies 2), which contains discrete glauconite peloids and glauconite grains (Plate 2, Fig. 4) within $41 \%$ of its noncarbonate SRF (Table 2).

Feldspar types were not studied in detail, but most facies contain both fresh and highly altered (weathered) feldspar grains. Facies 5 contains the highest percentage of altered feldspars.

\section{Facies 1, Gravel-Bearing Units}

\section{Lithotype A}

The principal feature of this lithotype is its abundance of carbonate rock fragments, of which $80 \%$ are dolostone. Siliciclastic components are quartz, feldspar, coarse "igneous" rock fragments, and red and drab sedimentary rock fragments. Recycled quartz grains (overgrowths and $\rho>4$ ) form about $10 \%$ of the quartz population. 
Table 1. Mineralogy of light fractions at Site $\mathbf{6 4 5}$.

\begin{tabular}{|c|c|c|c|c|c|c|c|c|c|c|c|c|c|}
\hline \multirow{2}{*}{$\begin{array}{l}\text { Core/section } \\
\text { interval }(\mathrm{cm})\end{array}$} & \multicolumn{8}{|c|}{ Major components } & \multicolumn{4}{|c|}{ Quartz varieties } & \multirow{2}{*}{$\frac{\text { Dolo }^{3}}{\text { Dolo }+ \text { Calo }}$} \\
\hline & Qtz & Feld & SRF & CRF & VRF & MRF & Oxide $^{1}$ & $\mathrm{Hvy} / \mathrm{Mica}^{2}$ & Overgth & $\rho>4$ & $\rho<4$ & in IRF & \\
\hline \multicolumn{14}{|l|}{ Facies 1: Lithotype A } \\
\hline 105-645B-1X-01, 50-53 & 29.2 & 9.2 & 1.2 & 59.6 & - & - & - & - & 2 & 3 & 82 & 13 & 0.8 \\
\hline 645B-1X-01, $100-102$ & 58.0 & 12.4 & 3.6 & 21.2 & - & - & - & 4.8 & 10 & 9 & 71 & 10 & 0.7 \\
\hline $645 \mathrm{~B}-5 \mathrm{X}-02,85-88$ & 35.6 & 8.4 & 2.8 & 50.8 & - & 0.8 & - & 1.6 & 9 & 3 & 84 & 4 & 0.7 \\
\hline $645 \mathrm{~B}-5 \mathrm{X}-03,93-96$ & 54.8 & 5.6 & 2.4 & 36.0 & - & - & - & 1.2 & 7 & 3 & 86 & 4 & 0.7 \\
\hline $645 B-9 X-03,71-74$ & 54.0 & 7.2 & 0.8 & 36.8 & - & - & $0.4 \mathrm{G}$ & 0.8 & 1 & 5 & 90 & 4 & 0.6 \\
\hline $645 \mathrm{~B}-11 \mathrm{X}-03,42-47$ & 52.8 & 13.6 & 5.6 & 27.2 & - & - & - & 0.8 & 4 & 7 & 81 & 8 & 0.7 \\
\hline $645 \mathrm{~B}-13 \mathrm{X}-04,46-51$ & 44.8 & 7.6 & 4.0 & 33.6 & - & - & 9.6 & 0.4 & 1 & 6 & 81 & 12 & 0.6 \\
\hline $645 \mathrm{~B}-15 \mathrm{X}-01,30-36$ & 36.0 & 5.2 & 2.8 & 54.0 & - & - & 1.6 & 0.4 & 2 & 6 & 88 & 4 & 0.7 \\
\hline $645 \mathrm{G}-1 \mathrm{H}-03,60-62$ & 52.4 & 20.4 & 0.4 & 24.4 & - & - & - & 2.4 & 2 & 8 & 81 & 9 & 0.8 \\
\hline Means & 46.4 & 10.0 & 2.6 & 38.2 & - & 0.1 & 1.3 & 1.4 & 4.2 & 5.6 & 82.7 & 7.6 & 0.70 \\
\hline \multicolumn{14}{|l|}{ Facies 1: Lithotype B } \\
\hline $645 \mathrm{C}-3 \mathrm{H}-03,111-113$ & 48.0 & 14.8 & 3.2 & 33.2 & - & - & - & 0.8 & 3 & 4 & 80 & 13 & 0.5 \\
\hline $645 \mathrm{~F}-3 \mathrm{H}-02,130-132$ & 71.2 & 8.0 & 10.4 & 5.6 & 0.4 & 0.4 & 2.4 & - & 13 & 11 & 71 & 5 & 0.5 \\
\hline $645 \mathrm{~F}-3 \mathrm{H}-05,70-72$ & 76.0 & 6.0 & 9.6 & 6.4 & 0.4 & - & 0.4 & 1.2 & 18 & 7 & 74 & 1 & 0.6 \\
\hline $645 \mathrm{G}-1 \mathrm{H}-05,4-6$ & 66.8 & 10.0 & 2.8 & 17.6 & - & - & - & 2.8 & 3 & 5 & 85 & 7 & 0.9 \\
\hline Means & 65.5 & 9.7 & 6.5 & 15.7 & 0.2 & 0.1 & 0.7 & 1.2 & 9.3 & 6.8 & 77.5 & 6.5 & 0.63 \\
\hline \multicolumn{14}{|l|}{ Facies 1: Lithotype C } \\
\hline $645 \mathrm{~B}-1 \mathrm{X}-02,120-122$ & 60.4 & 10.8 & 12.8 & 12.4 & 2.0 & - & - & 1.6 & 7 & 5 & 85 & 3 & 0.7 \\
\hline $645 \mathrm{~B}-1 \mathrm{X}-03,50-53$ & 63.6 & 16.8 & 2.8 & 12.4 & - & - & 0.8 & 1.6 & 4 & 5 & 88 & 3 & 0.7 \\
\hline $645 \mathrm{~B}-3 \mathrm{X}-02,40-43$ & 64.4 & 16.8 & 1.2 & 12.0 & 0.8 & - & 1.2 & 3.6 & 3 & 0 & 97 & 0 & 0.6 \\
\hline $645 \mathrm{~B}-8 \mathrm{X}-01,58-61$ & 59.6 & 16.8 & 6.8 & 14.4 & - & - & - & 2.4 & 4 & 6 & 89 & 1 & 0.9 \\
\hline $645 \mathrm{~B}-9 \mathrm{X}-02,27-30$ & 62.8 & 13.6 & 0.8 & 20.8 & - & 0.4 & - & 1.6 & 0 & 5 & 95 & 0 & 1.0 \\
\hline $645 B-10 X-01,39-44$ & 44.4 & 10.4 & 16.8 & 27.2 & - & - & - & 1.2 & 7 & 5 & 87 & 1 & 0.8 \\
\hline $645 \mathrm{~B}-11 \mathrm{X}-01,43-48$ & 58.8 & 19.2 & 3.2 & 14.0 & 0.4 & 2.8 & 0.4 & 1.2 & 4 & 7 & 84 & 5 & 0.7 \\
\hline $645 \mathrm{~B}-18 \mathrm{X}-01,50-54$ & 58.8 & 11.6 & 6.0 & 21.6 & 1.6 & - & - & 0.4 & 2 & 9 & 87 & 2 & 1.0 \\
\hline $645 \mathrm{~F}-2 \mathrm{H}-01,53-55$ & 66.8 & 14.4 & 2.0 & 15.6 & 0.2 & - & - & 0.4 & 2 & 1 & 86 & 11 & 0.8 \\
\hline $645 \mathrm{G}-2 \mathrm{H}-01,101-103$ & 65.2 & 17.2 & 4.8 & 11.6 & - & - & - & 1.2 & 2 & 14 & 79 & 5 & 0.9 \\
\hline Means & 60.5 & 14.8 & 5,7 & 16.2 & 0.5 & 0.3 & 0.2 & 1.5 & 3.5 & 5.7 & 87.7 & 3.1 & 0.81 \\
\hline \multicolumn{14}{|l|}{ Facies 1: Lithotype D } \\
\hline $645 \mathrm{~B}-22 \mathrm{X}-01,118-123$ & 55.6 & 17.6 & 15.2 & 3.2 & 2.0 & 1.2 & 2.0 & 3.2 & 5 & 5 & 84 & 6 & 0.9 \\
\hline $645 \mathrm{~B}-22 \mathrm{X}-03,118-123$ & 68.8 & 16.0 & 7.6 & 4.8 & - & 0.8 & 0.4 & 1.6 & 3 & 2 & 84 & 11 & 0.8 \\
\hline $645 \mathrm{~B}-23 \mathrm{X}-02,29-35$ & 62.8 & 22.0 & 2.4 & 5.2 & - & - & 2.4 & 5.2 & 2 & 9 & 76 & 13 & 0.95 \\
\hline $645 \mathrm{~B}-27 \mathrm{X}-02,48-53$ & 26.8 & 5.2 & 61.2 & 0.4 & - & - & 0.4 & $6.0 \mathrm{M}$ & nd & nd & nd & nd & N/A \\
\hline Means & 53.5 & 15.2 & 21.6 & 3.4 & 0.5 & 0.5 & 1.3 & 4.0 & 3.3 & 5.3 & 81.3 & 10.0 & 0.9 \\
\hline \multicolumn{14}{|l|}{ Facies 2} \\
\hline $645 \mathrm{~B}-1 \mathrm{X}-01,118-120$ & 54.8 & 26.4 & 2.0 & 6.4 & 2.8 & 4.4 & - & 3.2 & 1 & 2 & 89 & 8 & 0.8 \\
\hline $645 \mathrm{~B}-2 \mathrm{X}-01,31-34$ & 57.2 & 28.0 & 2.0 & 7.6 & - & - & - & 2.4 & 3 & 0 & 86 & 11 & 0.9 \\
\hline $645 \mathrm{C}-3 \mathrm{H}-04,39-41$ & 65.6 & 14.8 & 10.4 & 3.6 & - & 0.2 & $0.4 \mathrm{G}$ & 2.2 & 1 & 0 & 94 & 5 & 0.9 \\
\hline $645 \mathrm{~F}-3 \mathrm{H}-02,11-13$ & 62.4 & 27.2 & 0.4 & 6.4 & - & - & - & 3.2 & 5 & 2 & 90 & 3 & 1.0 \\
\hline $645 \mathrm{~F}-3 \mathrm{H}-02,111-113$ & 54.4 & 13.6 & 4.4 & 26.8 & - & - & - & 0.8 & 2 & 6 & 88 & 4 & 0.5 \\
\hline Means & 58.9 & 22.0 & 3.8 & 10.2 & 0.6 & 0.9 & $\operatorname{tr}$ & 2.4 & 2.4 & 2.0 & 89.4 & 6.2 & 0.82 \\
\hline \multicolumn{14}{|l|}{ Facies 3} \\
\hline $645 \mathrm{~B}-14 \mathrm{X}-04,2-8$ & 49.3 & 9.3 & 2.7 & 38.7 & - & - & - & - & nd & nd & nd & nd & 0.8 \\
\hline $645 \mathrm{~F}-2 \mathrm{H}-01,85-87$ & 47.2 & 20.8 & 2.0 & 24.4 & 0.4 & - & - & 2.0 & 8 & 5 & 82 & 5 & 0.7 \\
\hline Means & 48.3 & 15.0 & 2.4 & 31.6 & 0.2 & - & - & 1.0 & 8 & 5 & 82 & 5 & 0.75 \\
\hline Facies 4 & & & & & & & & & & & & & \\
\hline $645 \mathrm{~B}-30 \mathrm{X}-01,42-46$ & 68.0 & 22.0 & 3.6 & 3.2 & 0.8 & - & $0.4 \mathrm{G}$ & 2.0 & 4 & 5 & 86 & 5 & 1.0 \\
\hline $645 \mathrm{~B}-30 \mathrm{X}-02,20-24$ & 70.8 & 18.0 & 4.0 & 5.2 & - & - & - & 2.0 & nd & nd & nd & nd & 1.0 \\
\hline $645 \mathrm{~B}-32 \mathrm{X}-06,105-110$ & 76.8 & 15.2 & 1.6 & 5.2 & - & - & 1.2 & - & 4 & 10 & 84 & 2 & 1.0 \\
\hline $645 \mathrm{D}-2 \mathrm{R}-04,36-41$ & 55.6 & 19.2 & 12.4 & 2.0 & 1.2 & 0.4 & - & $9.2 \mathrm{M}$ & 4 & 12 & 80 & 4 & 1.0 \\
\hline Means & 67.8 & 18.6 & 5.4 & 3.9 & 0.5 & 0.1 & 0.4 & 3.3 & 4.0 & 9.0 & 83.3 & 3.7 & 1.0 \\
\hline Facies 5 & & & & & & & & & & & & & \\
\hline $645 \mathrm{D}-10 \mathrm{R}-02,20-25$ & 44.0 & 12.8 & 28.0 & 4.8 & 0.4 & - & 2.0 & $8.0 \mathrm{M}$ & 8 & 7 & 83 & 2 & 1.0 \\
\hline $645 \mathrm{D}-14 \mathrm{R}-05,30-35$ & 72.0 & 10.4 & 2.8 & 4.0 & 0.4 & - & 6.8 & $3.6 \mathrm{M}$ & 5 & 11 & 84 & - & 1.0 \\
\hline $645 \mathrm{D}-20 \mathrm{R}-01,24-29$ & 70.0 & 14.8 & 10.0 & 1.2 & - & 0.4 & 1.2 & $2.4 \mathrm{M}$ & 5 & 15 & 80 & - & 1.0 \\
\hline 645E-6R-01, 93-98 & 54.4 & 11.6 & 23.6 & 1.6 & 0.4 & - & - & $8.4 \mathrm{M}$ & & & & & \\
\hline $645 \mathrm{E}-6 \mathrm{R}-03,88-93$ & 48.8 & 16.0 & 24.8 & 0.4 & - & - & 2.0 & $8.0 \mathrm{M}$ & nd & nd & nd & nd & 1.0 \\
\hline $645 \mathrm{E}-8 \mathrm{R}-01,59-64$ & 38.0 & 12.8 & 39.2 & 0.4 & - & - & $1.2 \mathrm{G}$ & $8.4 \mathrm{M}$ & nd & nd & nd & nd & N/A \\
\hline $645 \mathrm{E}-9 \mathrm{R}-06,59-64$ & 9.6 & 3.2 & 84.0 & - & - & - & - & $3.2 \mathrm{M}$ & nd & nd & nd & nd & $\mathrm{N} / \mathrm{A}$ \\
\hline $645 \mathrm{E}-12 \mathrm{R}-05,61-65$ & 24.4 & 6.8 & 62.0 & - & - & - & 0.4 & $6.0 \mathrm{M}$ & nd & nd & nd & nd & $\mathrm{N} / \mathrm{A}$ \\
\hline Means & 45.2 & 11.1 & 34.3 & 1.6 & 0.2 & $\operatorname{tr}$ & 1.7 & $6.0 \mathrm{M}$ & & & & & \\
\hline
\end{tabular}

1 Iron oxides, except where marked "G" to indicate significant glauconite.

${ }^{2} \mathrm{M}=$ Micas predominant in this component.

${ }^{3} \mathrm{Qtz}=$ quartz; Feld = feldspar; SRF = sedimentary rock fragments; CRF = carbonate rock fragments; VRF = volcanic rock fragments; $\mathrm{MRF}=$ metamor phic rock fragments; $\mathrm{Hvy}=$ heavy minerals; Overgth = quartz grains with abraded overgrowths; $I R F=$ igneous rock fragments; Dolo $=$ dolomite; Calc $=$ calcite; $-=$ not observed; $\mathrm{tr}=$ trace; $\mathrm{nd}=$ not determined; $\mathrm{N} / \mathrm{A}=$ not applicable.

Note: Numbers are percentages of total grains counted. 
Table 2. Lithologies of noncarbonate sedimentary rock fragments of sand size at Site 645 .

\begin{tabular}{|c|c|c|c|c|c|c|}
\hline \multirow[b]{2}{*}{$\begin{array}{l}\text { Core/section } \\
\text { interval }(\mathrm{cm})\end{array}$} & \multicolumn{6}{|c|}{ Lithology } \\
\hline & $\begin{array}{l}\text { Red } \\
\text { shale }\end{array}$ & Shale & $\begin{array}{c}\text { Red } \\
\text { silt/sst }\end{array}$ & Silt/sst & $\begin{array}{l}\text { Quartz- } \\
\text { arenite }\end{array}$ & $\begin{array}{l}\text { Signif. } \\
\text { glauc. }\end{array}$ \\
\hline \multicolumn{7}{|l|}{ Facies 1: Lithotype A } \\
\hline $105-645 \mathrm{~B}-11 \mathrm{X}-03,42-47$ & - & 22 & - & 58 & 20 & - \\
\hline \multicolumn{7}{|l|}{ Facies 1: Lithotype B } \\
\hline $645 \mathrm{~F}-3 \mathrm{H}-02,130-132$ & 33 & 4 & 23 & 35 & 5 & - \\
\hline $645 \mathrm{~F}-3 \mathrm{H}-05,70-72$ & 28 & 22 & 13 & 19 & 18 & - \\
\hline \multicolumn{7}{|l|}{ Facies 1: Lithotype C } \\
\hline $645 \mathrm{~B}-1 \mathrm{X}-02,120-122$ & - & 95 & - & 5 & - & - \\
\hline $645 \mathrm{~B}-10 \mathrm{X}-01,39-44$ & 84 & 8 & - & 8 & - & - \\
\hline \multicolumn{7}{|l|}{ Facies 1: Lithotype D } \\
\hline $645 \mathrm{~B}-22 \mathrm{X}-01,118-123$ & 14 & 9 & 37 & 13 & 27 & - \\
\hline $645 \mathrm{~B}-27 \mathrm{X}-02,48-53$ & - & 100 & - & - & - & - \\
\hline \multicolumn{7}{|l|}{ Facies 2} \\
\hline $645 \mathrm{C}-3 \mathrm{H}-04,39-41$ & 3 & 31 & 4 & 21 & - & $1_{41}$ \\
\hline \multicolumn{7}{|l|}{ Facies 4} \\
\hline $645 \mathrm{~B}-32 \mathrm{X}-06,105-110$ & 95 & 5 & - & - & - & - \\
\hline $645 \mathrm{D}-2 \mathrm{R}-04,36-41$ & - & 100 & - & - & - & - \\
\hline \multicolumn{7}{|l|}{ Facies 5} \\
\hline $645 \mathrm{D}-10 \mathrm{R}-02,20-25$ & - & 100 & - & - & $\operatorname{tr}$ & - \\
\hline 645D-20R-01, 24-29 & - & 100 & - & - & - & - \\
\hline 645E-6R-01, 93-98 & - & 100 & - & - & - & - \\
\hline 645E-6R-03, 88-93 & - & 100 & - & - & - & - \\
\hline 645E-8R-01, 59-64 & - & 100 & - & - & - & - \\
\hline 645E-9R-06, 59-64 & - & 100 & - & - & - & - \\
\hline $645 \mathrm{E}-12 \mathrm{R}-05,61-65$ & - & 100 & - & - & - & - \\
\hline
\end{tabular}

${ }^{1}$ This is an anomalous sample; others contain little or no glauconite. Note: Numbers are percentages of total grains counted.

\section{Lithotype B}

Carbonate content of this lithotype varies, but in all cases the overall color of the sediment is the result of red SRF, ironoxide grains, and red hematite coatings on quartz grains. These hematite coatings predate relict quartz overgrowths present on some of the grains. The apparent proportion of recycled quartz (overgrowths and $\rho>4$ ) is higher in this lithotype than in any other lithotype or facies (about 16\%). As noted above, the actual proportion of recycled quartz grains may be higher. This quartz comes from an essentially monomineralic source (quartzarenite), so that the ratio of quartz to feldspar is higher in this lithotype than in all others (about 6.8).

Although quantitative data are based on only two samples (Table 2), the variety of noncarbonate SRF is greater in this lithotype than in any other lithotype or facies.

\section{Lithotype C}

This lithotype is characterized by a relatively low proportion of highly rounded quartz grains or grains with overgrowths, moderate carbonate content, and relatively high feldspar content, although the quartz/feldspar ratio is much like that of lithotype A. Volcanic clasts appear to be more common than in other Facies 1 lithotypes. Noncarbonate sedimentary clasts are both red and drab, but we did not observe quartzarenite clasts.

\section{Lithotype D}

This lithotype corresponds to lithologic Unit II, in which shipboard analyses indicated a sharp decrease in carbonate con- tent and an increase in the dolomite/calcite ratio relative to lithologic Unit I. The proportion of carbonate rock fragments is indeed low, and most carbonate rock fragments are finely crystalline dolostone. Feldspar content is relatively high (quartz/ feldspar $=3.5$ ), although this is probably partly due to the finer grain size of lithologic Unit II relative to Unit I (Blatt, 1982, p. 162).

Sample 105-645B-27X-02, 48-53 cm, contains the highest occurrence of significant diatomaceous, brown, silty mudstone clasts, such as those that characterize Facies 5 (Subunit IIIA). As in Facies 5, these are associated with abundant silt-sized mica flakes.

\section{Facies 2, Gray Silty Clays and Silty Muds}

The examined samples from this facies contain sand that is either scattered throughout the mud or concentrated in thin pebbly and sandy layers. In general, carbonate content is low, and feldspar content is high (quartz/feldspar ratio $=2.7$ ), probably due to fine grain size. The one sample that contained enough SRF for detailed study also contained a high proportion of glauconite-bearing sedimentary clasts and very few red sedimentary clasts.

\section{Facies 3, Laminated Detricarbonate Silty Muds}

A limited number of samples were available for studying this facies. As for Facies 2, the sand fraction probably represents an ice-rafted component associated with deposition of the finer sediment. As expected, mineralogy was indistinguishable from 
that of Facies 1, lithotype A, which has the same tan color in cores. Predominant components are quartz and carbonate rock fragments.

\section{Facies 4, Silty Sand}

Samples of this facies are either well-sorted, very fine sand, or the same sediment with scattered medium and coarse sand grains of predominantly quartz, many of which are well rounded. Minor amounts of volcanic and schistose detritus occur, and all carbonate grains are dolomite. In Sample 105-645D-2R-04, 36$41 \mathrm{~cm}$, mudstone clasts containing silt-sized micas, diatoms, and spicules (see Facies 5) are common. Glauconite peloids are present but rare. Because of within-sample contamination, several heavy-mineral grains were encountered in thin sections, including slightly serpentinized olivine.

\section{Facies 5, Muddy Sands and Silty Muds of Subunit IIIA}

Thin sections from this facies have an entirely different aspect compared to most samples from the other facies. Grain size is generally fine, and mica flakes are common. Carbonate abundance is low (all dolomite). Most samples contain a high proportion of dark brown, silty shale clasts that are in various states of disaggregation. The size distribution of many of the quartz and feldspar grains is identical to the size distribution of these minerals in the silty shale clasts, which suggests that the mineral grains were liberated by disintegration of shale clasts. Feldspars are generally highly altered. Iron oxide clasts are present in most samples, and scattered glauconite peloids commonly occur.

Two samples (105-645D-10R-02, 20-25 cm and 105-645E-9R$06,59-64 \mathrm{~cm}$ ) are characterized by shale clasts rich in diatoms and spicules.

\section{SAND COMPOSITION-HEAVY FRACTION}

The true heavy-mineral contents of the sand fractions of each facies cannot be known accurately because of recurring contamination problems when using sodium polytungstate liquid. In addition, some samples contain considerable authigenic pyrite. For these reasons, we do not present a sample-by-sample tabulation of yields. Mean yields, excluding three anomalous samples (heavy-liquid crystals, authigenic pyrite), are as follows: (1) lithotype A, $1.9 \%$; (2) lithotype B, $0.7 \%$; (3) lithotype C, $1.5 \%$; (4) lithotype D, $1.3 \%$; (5) Facies $2,3.0 \%$; (6) Facies 3, $1.2 \%$; (7) Facies $4,2.0 \%$; and (8) Facies $5,1.1 \%$. To these percentages should be added the heavy-component present in the "light" fraction (Table 1), except for samples that contain abundant silt-sized micas (included with heavy minerals in Table 1), such as all samples from Facies 5. In general, this increment to the percentages given above is about $1 \%-2 \%$, although one must remember that imprecision is great when determining very minor components by point counting of 250 points (Pettijohn et al., 1973, p. 587). Note that the four Facies 4 samples, even with heavy minerals in the light fraction added, do not contain the high proportion of heavy minerals suggested by smear slides examined on board the ship. Instead, the heavy-mineral content is about $3 \%-4 \%$.

We have no reason to believe that failure to achieve a clean separation of heavy and light minerals results in a bias toward certain heavy minerals in the heavy-mineral separates. Those heavy minerals identified in the light-mineral thin sections are the same as those in the corresponding heavy mineral mount and have the same relative abundances.

Table 3 presents the heavy-mineral data. For all facies, the main types are hornblende, colorless garnet, and pyroxenes. Although potentially useful, hornblende color types were not distinguished quantitatively. Hornblende ranges in pleochroic scheme from (1) pale green to blue-green and (2) brown or brownish-yellow to dark green (nearly opaque). Grains are generally unaltered.

Garnet occurs in two color groups: pale pink to deep salmon pink, and colorless. The colorless garnets predominate, and many are well rounded, particularly in lithotype B of Facies 1 (Plate 2, Fig. 5). One sample of lithotype B contains $85 \%$ colorless, rounded garnet in the nonmicaceous, translucent assemblage. Garnets also may be very angular or strongly etched.

Clinopyroxenes are augite and diopside, with extinction angles on the order of $40^{\circ}$ and, in some cases, with narrowly spaced parting (diallage). Many grains have ragged prism terminations characterized by numerous pyramidal extensions. One sample of lithotype A, Facies 1, is rich in elongated crystals of aegirine having a near-zero extinction angle (Plate 2, Fig. 6). This particular clinopyroxene is either of minor abundance or is not present in all other samples. The orthopyroxenes are hypersthene (pink-green pleochroism) and green or colorless enstatite. In Facies 1 and 2, hypersthene is more abundant than enstatite; in Facies 4, these are subequal; and in Facies 3 and 5, enstatite is the most abundant orthopyroxene.

Minor amounts of the mineral olivine occur, except in two samples from the well-sorted, silty sands of Facies 4, where abundances are about $10 \%$. The garnets in this facies also appear to be different from those in other facies in that they contain abundant vermiform vacuoles.

\section{SILT COMPOSITION}

Information about silt composition is based on X-ray-diffraction data (Table 4), which are confined to Unit I (Facies 1, lithotypes A, B, and C; Facies 2; Facies 3). Relative to the sand fraction, quartz abundances in the silt fraction are lower by about $50 \%$; feldspar abundances in most cases are higher by about $50 \%$; and the amounts of detrital carbonate are significantly higher. In lithotypes A and B, alkali feldspar and plagioclase are subequal, whereas in all other facies and lithotypes, plagioclase is about twice as abundant as alkali feldspar.

Detrital carbonate is a significant component of all facies but is most abundant in tan-colored units (lithotype A and Facies 3). The ratio of dolomite to calcite is between $4: 1$ and $5: 1$, except in Facies 2, where it is about 8:1.

\section{COMPOSITION OF THE CLAY-SIZE FRACTION}

An important characteristic of all lithotypes and facies is that clay minerals (phyllosilicates) constitute only $25 \%-60 \%$ of the clay-size fraction (Table 5, column 1). Facies 2 is the only facies having more than $50 \%$ clay minerals in the clay-size range. This facies also has the lowest ratio of silt/(silt + clay) (Table 4, column 1).

Composition of the clay-size fraction is presented in two ways. In Table 5, clay minerals and nonclay minerals are recalculated separately to totals of $100 \%$. In Table 6 , the means for each lithotype and facies are adjusted, based on the mean percentage of clay minerals, so that the mineralogy of the entire clay-size fraction totals $100 \%$.

Examination of Table 5 indicates that there is little variation in proportions of clay minerals among the facies of Unit I (for clay proportions at deeper levels in Site 645 holes, see Thiebault et al., this volume). Illite predominates, followed in importance by kaolinite, smectite, and chlorite. Exceptions are lithotype B, for which kaolinite is approximately as abundant as illite, and Facies 2, for which smectite > kaolinite. The seven samples from lithologic Subunit IB (72-170 mbsf, deeper than Core 105645B-9X), have an unusually low proportion of smectite (mean of $6.4 \%$ ).

In the nonclay fraction (Table 5, right), clay-sized dolomite and quartz are predominant, except for Facies 2, which is relatively poor in dolomite but relatively rich in feldspar, mostly 
R. N. HISCOTT, A. E. AKSU, O. B. NIELSEN

Table 3. Mineralogy of heavy fractions at Site 645 .

\begin{tabular}{|c|c|c|c|c|c|c|c|c|c|c|c|c|c|c|c|c|}
\hline $\begin{array}{l}\text { Core/section. } \\
\text { interval }(\mathrm{cm})\end{array}$ & Hbld $^{1}$ & $\begin{array}{l}\text { Clino- } \\
\text { pyrox }\end{array}$ & $\begin{array}{l}\text { Aegir- } \\
\text { ine }\end{array}$ & Hyper & Enstat & Oliv & Gar & C & $\begin{array}{l}\text { Epidote } \\
\text { group }\end{array}$ & $\begin{array}{l}\text { Xeno/ } \\
\text { Zircon }\end{array}$ & Sphene & Tour & $\begin{array}{c}\text { Kyan + } \\
\text { Staur }\end{array}$ & Apatite & $\begin{array}{c}\text { ?Idocr/ } \\
\text { Topaz }\end{array}$ & Others \\
\hline $105-645 \mathrm{~B}-1 \mathrm{X}-01,50-53$ & 58 & 1 & 1 & 4 & 1 & - & 1 & 14 & 13 & 1 & - & 1 & - & - & - & 5 \\
\hline 645B-1X-01, $100-102$ & 33 & - & 25 & 9 & 2 & - & 4 & 16 & 3 & 3 & 2 & - & 1 & - & - & 2 \\
\hline $645 \mathrm{~B}-5 \mathrm{X}-02,85-88$ & 41 & - & - & 4 & 1 & - & - & 24 & 14 & 7 & - & 4 & 2 & 1 & - & 2 \\
\hline $645 B-5 X-03,93-96$ & 42 & 4 & - & 8 & 3 & - & 1 & 20 & 13 & 3 & 2 & - & 1 & - & 1 & 2 \\
\hline $645 B-9 X-03,71-74$ & 40 & 4 & - & 6 & 3 & - & 3 & 34 & 7 & - & - & 3 & - & - & - & - \\
\hline $645 \mathrm{~B}-11 \mathrm{X}-03,42-47$ & 47 & 7 & - & 10 & 2 & - & 5 & 14 & 3 & 2 & 1 & - & 1 & 7 & - & 1 \\
\hline $645 B-13 X-04,46-51$ & 16 & 5 & - & 15 & 11 & - & 3 & 34 & 3 & 2 & - & 4 & - & 6 & - & 1 \\
\hline $645 B-15 X-01,30-36$ & 30 & 4 & - & 9 & 5 & - & 3 & 32 & 2 & 1 & 1 & 1 & - & 9 & 1 & 2 \\
\hline $645 \mathrm{G}-1 \mathrm{H}-03,60-62$ & 60 & 5 & - & 5 & 4 & - & 2 & 12 & 5 & - & - & - & - & 4 & $i$ & 2 \\
\hline Means & 40.8 & 3.4 & 2.9 & 7.8 & 3.6 & - & 2.5 & 22.2 & 7.0 & 2.2 & 0.6 & 1.4 & 0.5 & 3.0 & 0.4 & 1.9 \\
\hline
\end{tabular}

Facies 1: Lithotype B

\begin{tabular}{|c|c|c|c|c|c|c|c|c|c|c|c|c|c|c|c|}
\hline $645 \mathrm{C}-3 \mathrm{H}-03,111-113$ & 52 & 4 & - & 7 & 2 & - & 4 & 11 & 10 & 5 & - & 1 & 3 & - & - \\
\hline $645 \mathrm{~F}-3 \mathrm{H}-02,130-132$ & 28 & - & - & 6 & 4 & - & 12 & 27 & 11 & 2 & 5 & 2 & 2 & - & - \\
\hline $645 \mathrm{~F}-3 \mathrm{H}-05,70-72$ & 9 & - & - & 1 & 1 & - & - & $85 \mathrm{R}$ & - & 2 & - & - & - & - & - \\
\hline $645 \mathrm{G}-1 \mathrm{H}-05,4-6$ & 59 & 11 & - & 4 & 5 & 1 & 1 & 5 & 4 & 4 & 1 & 3 & 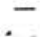 & - & 1 \\
\hline Means & 37.0 & 3.8 & - & 4.5 & 3.0 & 0.3 & 4.3 & 32.0 & 6.2 & 3.3 & 1.5 & 1.5 & 1.3 & - & 0.3 \\
\hline
\end{tabular}

Facies 1: Lithotype $C$

645B-1X-02, 120-122

645B-1X-03, 50-53

645B-3X-02, 40-43

645B-8X-01, 58-61

645B-9X-02, 27-30

645B-10X-01, 39-4

645B-11X-01, 43-48

645B-18X-01, 50-54

645F-2H-01, 53-55

645G-2H-01, 101-103

Means

$\begin{array}{lrl}49 & 2 & - \\ 44 & 3 & - \\ 45 & 6 & - \\ 45 & 5 & - \\ 44 & 13 & - \\ 57 & 4 & - \\ 53 & 4 & - \\ 43 & 6 & - \\ 51 & 3 & - \\ 63 & 6 & 1 \\ 49.4 & 5.2 & \mathrm{tr}\end{array}$

\begin{tabular}{lr}
- & 1 \\
- & 6 \\
- & 5 \\
- & 3 \\
- & 5 \\
- & 4 \\
- & 7 \\
$\overline{1}$ & 11 \\
tr & 9 \\
\hline
\end{tabular}

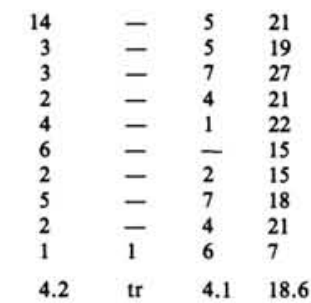

\begin{tabular}{rll}
\hline 5 & 1 & 3 \\
4 & 9 & 1 \\
11 & 1 & - \\
3 & 2 & 1 \\
5 & 1 & 2 \\
6 & - & 2 \\
3 & 4 & - \\
5 & 4 & 1 \\
2 & 2 & - \\
4.4 & 2.1 & 1.0
\end{tabular}

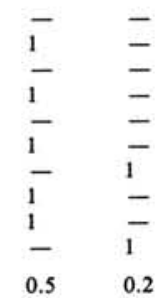

$\begin{array}{ll}- & 2 \\ - & 3 \\ - & 1 \\ - & 2 \\ - & 1 \\ - & 3 \\ & 7 \\ - & 1 \\ - & 2 \\ & 2 \\ 0 & 2.4\end{array}$

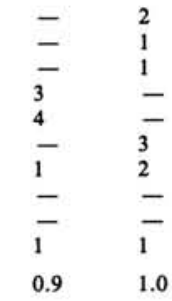

Facies 1: Lithotype D

\begin{tabular}{|c|c|c|c|c|c|c|c|c|c|c|c|c|c|c|c|c|}
\hline $645 \mathrm{~B}-22 \mathrm{X}-01,118-123$ & 11 & 4 & - & 8 & 13 & - & 6 & 39 & 5 & 6 & 1 & - & - & 1 & 6 & - \\
\hline $645 \mathrm{~B}-22 \mathrm{X}-03,118-123$ & 11 & 12 & - & 17 & 10 & - & 3 & 40 & 1 & 2 & - & - & - & 1 & 1 & 2 \\
\hline 645B-23X-02, 29-35 & 29 & 8 & - & 17 & 14 & - & 4 & 21 & 3 & - & - & 1 & - & - & 2 & 1 \\
\hline $645 \mathrm{~B}-27 \mathrm{X}-02,48-53$ & 31 & 11 & - & 8 & 5 & - & 8 & 23 & 5 & - & 4 & - & - & 1 & 1 & 3 \\
\hline Means & 20.5 & 8.8 & - & 12.5 & 10.5 & - & 5.3 & 30.7 & 3.5 & 2.0 & 1.3 & 0.3 & - & 0.8 & 2.5 & 1.5 \\
\hline
\end{tabular}

Facies 2

\begin{tabular}{|c|c|c|c|c|c|c|c|c|c|c|c|c|c|c|c|c|}
\hline $645 \mathrm{~B}-1 \mathrm{X}-01,118-120$ & 26 & - & - & 8 & - & - & 6 & 16 & 24 & 4 & 8 & 2 & - & - & 2 & 4 \\
\hline 645B-2X-01, 31-34 & 69 & 3 & - & 6 & 4 & - & 1 & 3 & 6 & 3 & 2 & 3 & - & - & - & - \\
\hline $645 \mathrm{C}-3 \mathrm{H}-04,39-41$ & 64 & - & - & 2 & 2 & - & 15 & 5 & 2 & 2 & - & 3 & - & 1 & - & 4 \\
\hline $645 \mathrm{~F}-3 \mathrm{H}-02,11-13$ & 60 & 2 & - & 11 & 2 & - & 1 & 8 & 8 & 2 & 4 & - & 1 & - & 1 & - \\
\hline $645 \mathrm{~F}-3 \mathrm{H}-02,111-113$ & 44 & 14 & - & 5 & 3 & - & 3 & 8 & 11 & 4 & 4 & 1 & 1 & - & 2 & - \\
\hline Means & 52.6 & 3.8 & - & 6.4 & 2.2 & - & 5.2 & 8.0 & 10.2 & 3.0 & 3.6 & 1.8 & 0.4 & 0.2 & 1.0 & 1.6 \\
\hline
\end{tabular}

Facies 3

645B-14H-04, 2-8

645B-2H-01, 85-87

All authigenic pyrite

Facies 4

\begin{tabular}{|c|c|c|c|c|c|c|c|c|c|c|c|c|c|c|c|c|}
\hline $645 \mathrm{~B}-30 \mathrm{X}-01,42-46$ & 47 & 11 & - & 8 & 8 & 8 & - & 8 & 3 & - & - & tr & - & 6 & - & 1 \\
\hline $645 \mathrm{~B}-30 \mathrm{X}-02,20-24$ & 54 & 13 & - & 6 & 9 & - & 2 & 8 & 5 & 1 & - & 1 & - & 1 & - & - \\
\hline $645 \mathrm{~B}-32 \mathrm{X}-06,105-110$ & 26 & 11 & - & 7 & 8 & 1 & 5 & 30 & 2 & 1 & - & tr & - & 8 & - & 1 \\
\hline 645D-2R-04, 36-41 & 52 & 9 & - & 6 & 5 & 11 & - & 5 & 4 & - & - & tr & - & 2 & - & 6 \\
\hline Means & 44.7 & 11.0 & - & 6.8 & 7.5 & 5.0 & 1.8 & 12.7 & 3.5 & 0.5 & - & 0.3 & - & 4.3 & - & 2.0 \\
\hline
\end{tabular}

Facies 5

645D-10R-02, 20-25 645D-14R-05, 30-35 645D-20R-01, 24-29 645E-6R-01, 93-98

645E-6R-03, 88-93

645E-8R-01, 59-64

645E-9R-06, 59-64

645E-12R-05, 61-65

Means

$\begin{array}{llllll}45 & 21 & - & 8 & 6 & - \\ 34 & 1 & - & - & 5 & - \\ 36 & 7 & - & 5 & 9 & - \\ 46 & - & - & - & 5 & - \\ 63 & 1 & - & 1 & 3 & - \\ 53 & 7 & - & 3 & 6 & - \\ 34 & 2 & - & 2 & 4 & - \\ 52 & 1 & - & - & 1 & - \\ 45.4 & 5.0 & - & 2.4 & 4.9 & -\end{array}$

$\begin{array}{lrl}- & 1 & 10 \\ - & 16 & 34 \\ - & 7 & 25 \\ - & 2 & 40 \mathrm{R} \\ - & 3 & 19 \\ - & 1 & 12 \mathrm{R} \\ - & 1 & 52 \mathrm{R} \\ - & 1 & 37 \\ - & 4.0 & 28.6\end{array}$

$\begin{array}{lllll}10 & 7 & 1 & - & - \\ 34 & 1 & 1 & - & 2 \\ 25 & 3 & 3 & 2 & 1 \\ 40 \mathrm{R} & 2 & 2 & - & 1 \\ 19 & 3 & 1 & - & 1 \\ 12 \mathrm{R} & 8 & 2 & 1 & 1 \\ 52 \mathrm{R} & 2 & - & - & - \\ 37 & 5 & 2 & 1 & - \\ 28.6 & 3.9 & 1.5 & 0.5 & 0.8\end{array}$

$\begin{array}{ll}- & - \\ 2 & - \\ 1 & - \\ 1 & 1 \\ 1 & - \\ - & - \\ - & - \\ 0.8 & 0.3\end{array}$

$\begin{array}{llll}- & - & 1 & - \\ - & 2 & 2 & 2 \\ - & 1 & - & 1 \\ 1 & - & - & 1 \\ - & - & 2 & 2 \\ - & - & 4 & 2 \\ - & - & - & 3 \\ 0.3 & 0.4 & 1.1 & 1.4\end{array}$

${ }^{1} \mathrm{Hbld}=$ hornblende Pyrox $=$ pyroxene Hyper = hypersthene Enstat $=$ enstatite Oliv = olivine P = pink garnets $\mathrm{C}=$ colorless garnets Xeno $=$ xenotime $;$ Tour $=$ tourmaline; Kyan $=$ kyanite; Staur $=$ staurolite; Idocr $=$ idocrase; $\mathbf{R}=$ indicator that the colorless garnets are particularly well rounded; tr $=$ trace; $-=$ not observed.

Note: Numbers are percentages of total grains counted. 
Table 4. Mineralogy of 2-63 $\mu \mathrm{m}$ fractions at Site 645 .

\begin{tabular}{|c|c|c|c|c|c|c|c|c|}
\hline \multirow[b]{2}{*}{$\begin{array}{l}\text { Core/section } \\
\text { interval }(\mathrm{cm})\end{array}$} & \multirow{2}{*}{$\begin{array}{c}\text { Texture } \\
\text { silt } \\
\text { silt }+ \text { clay }\end{array}$} & \multicolumn{7}{|c|}{ Major components ${ }^{1}$} \\
\hline & & Qtz & Alk F & Plag & Calc & Dolo & Pyrite & $\begin{array}{l}\text { Clay } \\
\text { min }\end{array}$ \\
\hline \multicolumn{9}{|l|}{ Facies 1: Lithotype A } \\
\hline $105-645 \mathrm{~B}-1 \mathrm{X}-01,50-53$ & 0.87 & 15 & 4 & 8 & 11 & 62 & 0 & 0 \\
\hline 645B-1X-01, 100-102 & 0.86 & 22 & 6 & 7 & 12 & 52 & 0 & 2 \\
\hline $645 \mathrm{~B}-5 \mathrm{X}-02,85-88$ & 0.87 & 17 & 6 & 7 & 9 & 58 & 1 & 2 \\
\hline $645 \mathrm{~B}-5 \mathrm{X}-03,93-96$ & 0.86 & 17 & 3 & 6 & 13 & 59 & 0 & 2 \\
\hline $645 \mathrm{~B}-9 \mathrm{X}-03,71-74$ & 0.75 & 19 & 6 & 4 & 19 & 52 & 0 & 1 \\
\hline $645 \mathrm{~B}-11 \mathrm{X}-03,42-47$ & 0.90 & 17 & 6 & 5 & 11 & 60 & $\mathrm{tr}$ & 1 \\
\hline $645 B-13 X-04,46-51$ & 0.86 & 16 & 3 & 3 & 14 & 62 & 0 & 2 \\
\hline $645 \mathrm{~B}-15 \mathrm{X}-01,30-36$ & 0.81 & 15 & 7 & 2 & 19 & 57 & 0 & 0 \\
\hline $645 \mathrm{G}-1 \mathrm{H}-03,60-62$ & 0.81 & 16 & 8 & 8 & 13 & 54 & tr & 2 \\
\hline Means & 0.84 & 17.1 & 5.4 & 5.6 & 13.4 & 57.3 & 0.0 & 1.3 \\
\hline \multicolumn{9}{|l|}{ Facies 1: Lithotype B } \\
\hline $645 \mathrm{C}-3 \mathrm{H}-03,111-113$ & 0.89 & 26 & 6 & 11 & 11 & 43 & $\mathrm{tr}$ & 2 \\
\hline $645 \mathrm{~F}-3 \mathrm{H}-02,130-132$ & 0.88 & 44 & 8 & 9 & 5 & 28 & 1 & 5 \\
\hline $645 \mathrm{~F}-3 \mathrm{H}-05,70-72$ & 0.86 & 37 & 7 & 6 & 5 & 40 & $\mathrm{tr}$ & 4 \\
\hline Means & 0.88 & 35.7 & 7.0 & 8.7 & 7.0 & 37.0 & 0.3 & 3.7 \\
\hline \multicolumn{9}{|l|}{ Facies 1: Lithotype C } \\
\hline $645 \mathrm{~B}-1 \mathrm{X}-02,120-122$ & 0.90 & 28 & 11 & 23 & 4 & 30 & $\operatorname{tr}$ & 4 \\
\hline $645 \mathrm{~B}-1 \mathrm{X}-03,50-53$ & 0.80 & 23 & 9 & 12 & 13 & 40 & 1 & 2 \\
\hline $645 \mathrm{~B}-3 \mathrm{X}-02,40-43$ & 0.80 & 31 & 9 & 17 & 9 & 33 & 1 & 2 \\
\hline $645 \mathrm{~B}-8 \mathrm{X}-01,58-61$ & 0.81 & 16 & 6 & 7 & 7 & 63 & 0 & 1 \\
\hline $645 \mathrm{~B}-9 \mathrm{X}-02,27-30$ & 0.82 & 22 & 4 & 10 & 11 & 51 & 0 & 2 \\
\hline $645 \mathrm{~B}-10 \mathrm{X}-01,39-44$ & 0.74 & 17 & 3 & 5 & 22 & 49 & tr & 2 \\
\hline $645 \mathrm{~B}-11 \mathrm{X}-01,43-48$ & 0.78 & 29 & 14 & 30 & 4 & 21 & 1 & 1 \\
\hline $645 \mathrm{~B}-18 \mathrm{X}-01,50-54$ & 0.85 & 25 & 6 & 9 & 10 & 49 & $\mathrm{tr}$ & 1 \\
\hline $645 \mathrm{~F}-2 \mathrm{H}-01,53-55$ & 0.89 & 26 & 10 & 11 & 8 & 42 & 1 & 1 \\
\hline $645 \mathrm{G}-2 \mathrm{H}-01,101-103$ & 0.81 & 29 & 5 & 9 & 13 & 44 & $\operatorname{tr}$ & 0 \\
\hline Means & 0.82 & 24.6 & 7.7 & 13.3 & 10.1 & 42.2 & 0.4 & 1.6 \\
\hline \multicolumn{9}{|l|}{ Facies 2} \\
\hline $645 \mathrm{~B}-1 \mathrm{X}-01,118-120$ & 0.52 & 37 & 11 & 24 & 4 & 18 & 1 & 5 \\
\hline $645 \mathrm{~B}-2 \mathrm{X}-01,31-34$ & 0.67 & 32 & 16 & 27 & 0 & 21 & 1 & 3 \\
\hline $645 \mathrm{C}-3 \mathrm{H}-04,39-41$ & 0.74 & 35 & 19 & 27 & 1 & 14 & 1 & 3 \\
\hline $645 \mathrm{~F}-3 \mathrm{H}-02,11-13$ & 0.75 & 33 & 11 & 26 & 2 & 25 & $\mathrm{tr}$ & 3 \\
\hline $645 \mathrm{~F}-3 \mathrm{H}-02,111-113$ & 0.84 & 27 & 11 & 12 & 7 & 39 & $\mathrm{tr}$ & 4 \\
\hline Means & 0.70 & 32.8 & 13.6 & 23.2 & 2.8 & 23.4 & 0.6 & 3.6 \\
\hline \multicolumn{9}{|l|}{ Facies 3} \\
\hline $645 \mathrm{~B}-14 \mathrm{X}-04,2-8$ & 0.80 & 16 & 2 & 2 & 17 & 59 & 2 & 2 \\
\hline $645 \mathrm{~F}-2 \mathrm{H}-01,85-87$ & 0.85 & 36 & 5 & 18 & 4 & 37 & $\operatorname{tr}$ & $\mathrm{tr}$ \\
\hline Means & 0.83 & 26.0 & 3.5 & 10.0 & 10.5 & 48.0 & 1.0 & 1.0 \\
\hline
\end{tabular}

plagioclase. The relative amounts of carbonate minerals are highest in the tan-colored lithotype A and Facies 3. In general, relative to the silt fraction (Table 4), quartz abundance is higher and dolomite abundance lower. Again, the exception is Facies 2, with its high relative proportion of clay-sized feldspars.

The mean compositions in Table 6 highlight the importance of clay-sized carbonate minerals, principally dolomite, in lithotype $\mathrm{A}$ and Facies 3 . Facies 2 has by far the highest ratio of feldspar to quartz, as well as the greatest amount of smectite and illite.

\section{PROVENANCE OF SEDIMENTS AT SITE 645}

\section{Primary Associations, End-Members, and Their Provenance}

In terms of mineralogical composition, we define an "endmember" as the mineral assemblage derived from a single source of uniform petrology. A "primary association" occurs when a single transportation process mixes minerals from two petrologically distinct sources that occur in one geographic area. For example, alternating limestones and shales will provide a primary association that consists of minerals from both lithologies. "Higher-order associations" are generated by complex mixing of two or more end-members.

In the Baffin Bay basin, ice rafting is the only sediment transporting agent likely to deposit pure end-members, provided that the ice overrides a petrologically homogeneous source rock. A glacier flowing over petrologically complex rocks, including more than one major rock type, will produce ice-rafted deposits having first-order primary associations. Additional mixing of mineral assemblages occurs when the ice-borne debris is deposited as a till or moraine. Long-distance transportation by icebergs and local resedimentation of dropped material into the deeper basin produces higher-order assemblages. For this reason, most Baffin Bay basinal sediments are composed of a complex mixture of materials from several end-member sources. 
Table 5. Mineralogy of $<2-\mu \mathrm{m}$-size fractions at Site 645 , clays and nonclays separate.

\begin{tabular}{|c|c|c|c|c|c|c|c|c|c|c|c|}
\hline \multirow{2}{*}{$\begin{array}{l}\text { Core/section } \\
\text { interval }(\mathrm{cm})\end{array}$} & \multirow{2}{*}{$\frac{\text { Clay } \min ^{1}}{\text { clay size }}$} & \multicolumn{4}{|c|}{ Clay minerals $=100 \%$} & \multicolumn{6}{|c|}{ Nonclay minerals $=100 \%$} \\
\hline & & Smect & Illite & Kaol & Chlor & Qtz & Alk F & Plag & Calc & Dolo & Pyrite \\
\hline \multicolumn{12}{|l|}{ Facies 1: Lithotype A } \\
\hline 105-645B-1X-01, 50-53 & 0.32 & 15 & 61 & 19 & 5 & 20 & 9 & 12 & 16 & 43 & 0 \\
\hline $645 \mathrm{~B}-1 \mathrm{X}-01,100-102$ & 0.14 & 13 & 51 & 36 & 0 & 26 & 7 & 14 & 0 & 53 & 0 \\
\hline $645 \mathrm{~B}-5 \mathrm{X}-02,85-88$ & 0.31 & 20 & 46 & 26 & 8 & 32 & 11 & 22 & 0 & 32 & 3 \\
\hline 645B-5X-03, 93-96 & 0.19 & 19 & 46 & 27 & 8 & 27 & 5 & 10 & 15 & 43 & 0 \\
\hline $645 \mathrm{~B}-9 \mathrm{X}-03,71-74$ & 0.23 & 18 & 45 & 29 & 8 & 23 & 6 & 8 & 26 & 37 & 0 \\
\hline $645 \mathrm{~B}-11 \mathrm{X}-03,42-47$ & 0.14 & 4 & 59 & 29 & 8 & 35 & 7 & 9 & 2 & 47 & 0 \\
\hline $645 \mathrm{~B}-13 \mathrm{X}-04,46-51$ & 0.28 & 3 & 43 & 40 & 14 & 25 & 6 & 7 & 7 & 55 & 0 \\
\hline $645 \mathrm{~B}-15 \mathrm{X}-01,30-36$ & 0.35 & 5 & 49 & 37 & 9 & 20 & 4 & 4 & 27 & 45 & 0 \\
\hline $645 \mathrm{G}-1 \mathrm{H}-03,60-62$ & 0.39 & 42 & 28 & 20 & 10 & 24 & 10 & 18 & 7 & 41 & 0 \\
\hline Means & 0.261 & 15.4 & 47.6 & 29.2 & 7.8 & 25.8 & 7.2 & 11.6 & 11.1 & 44.0 & 0.3 \\
\hline \multicolumn{12}{|l|}{ Facies 1: Lithotype B } \\
\hline $645 \mathrm{C}-3 \mathrm{H}-03,111-113$ & 0.36 & 17 & 38 & 34 & 11 & 31 & 8 & 16 & 7 & 38 & 0 \\
\hline $645 \mathrm{~F}-3 \mathrm{H}-02,130-132$ & 0.50 & 9 & 39 & 39 & 13 & 57 & 8 & 16 & 0 & 19 & 0 \\
\hline $645 \mathrm{~F}-3 \mathrm{H}-05,70-72$ & 0.51 & 16 & 37 & 36 & 10 & 54 & 8 & 14 & 0 & 24 & 0 \\
\hline Means & 0.457 & 14.0 & 38.0 & 36.3 & 11.3 & 47.3 & 8.0 & 15.3 & 2.3 & 27.0 & 0 \\
\hline \multicolumn{12}{|l|}{ Facies 1: Lithotype C } \\
\hline $645 \mathrm{~B}-1 \mathrm{X}-02,120-122$ & 0.30 & 0 & 61 & 32 & 7 & 48 & 13 & 20 & 0 & 19 & 0 \\
\hline $645 \mathrm{~B}-1 \mathrm{X}-03,50-53$ & 0.41 & 16 & 47 & 31 & 6 & 35 & 12 & 25 & 0 & 28 & 0 \\
\hline $645 \mathrm{~B}-3 \mathrm{X}-02,40-43$ & 0.39 & 21 & 48 & 25 & 6 & 45 & 12 & 18 & 0 & 25 & 0 \\
\hline $645 \mathrm{~B}-8 \mathrm{X}-01,58-61$ & 0.28 & 14 & 38 & 33 & 15 & 35 & 7 & 14 & 0 & 44 & 0 \\
\hline 645B-9X-02, 27-30 & 0.31 & 12 & 54 & 27 & 7 & 44 & 8 & 10 & 4 & 34 & 0 \\
\hline 645B-10X-01, 39-44 & 0.26 & 6 & 56 & 32 & 6 & 23 & 6 & 7 & 23 & 41 & 0 \\
\hline $645 \mathrm{~B}-11 \mathrm{X}-01,43-48$ & 0.49 & 21 & 55 & 17 & 8 & 35 & 20 & 45 & 0 & 0 & 0 \\
\hline $645 \mathrm{~B}-18 \mathrm{X}-01,50-54$ & 0.40 & 7 & 52 & 31 & 10 & 38 & 10 & 17 & 2 & 31 & 2 \\
\hline $645 \mathrm{~F}-2 \mathrm{H}-01,53-55$ & 0.29 & 21 & 45 & 25 & 9 & 32 & 11 & 23 & 1 & 30 & 3 \\
\hline $645 \mathrm{G}-2 \mathrm{H}-01,101-103$ & 0.33 & 40 & 24 & 27 & 9 & 36 & 9 & 21 & 2 & 32 & 0 \\
\hline Means & 0.346 & 15.8 & 48.0 & 28.0 & 8.3 & 37.1 & 10.8 & 20.0 & 3.2 & 28.4 & 0.5 \\
\hline \multicolumn{12}{|l|}{ Facies 2} \\
\hline $645 \mathrm{~B}-1 \mathrm{X}-01,118-120$ & 0.54 & 15 & 55 & 21 & 9 & 28 & 11 & 52 & 0 & 9 & 0 \\
\hline 645B-2X-01, 31-34 & 0.63 & 30 & 43 & 16 & 11 & 26 & 16 & 50 & 5 & 3 & 0 \\
\hline $645 \mathrm{C}-3 \mathrm{H}-04,39-41$ & 0.51 & 25 & 40 & 25 & 10 & 31 & 14 & 45 & 4 & 6 & 0 \\
\hline $645 \mathrm{~F}-3 \mathrm{H}-02,11-13$ & 0.64 & 30 & 34 & 30 & 6 & 24 & 18 & 45 & 8 & 5 & 0 \\
\hline $645 \mathrm{~F}-3 \mathrm{H}-02,111-113$ & 0.61 & 36 & 36 & 22 & 7 & 31 & 13 & 36 & 5 & 15 & 0 \\
\hline Means & 0.586 & 27.2 & 41.6 & 22.8 & 8.6 & 28.0 & 14.4 & 45.6 & 4.4 & 7.6 & 0 \\
\hline \multicolumn{12}{|l|}{ Facies 3} \\
\hline 645B-14X-04, 2-8 & 0.27 & 2 & 33 & 48 & 17 & 23 & 4 & 4 & 13 & 56 & 0 \\
\hline $645 \mathrm{~F}-2 \mathrm{H}-01,85-87$ & 0.52 & 27 & 47 & 19 & 8 & 30 & 14 & 29 & 0 & 27 & 0 \\
\hline Means & 0.395 & 14.5 & 40.0 & 33.5 & 12.5 & 26.5 & 9.0 & 16.5 & 6.5 & 41.5 & 0 \\
\hline
\end{tabular}

${ }^{1}$ Clay $\min =$ clay mineral percentage Smect $=$ smectite Kaol = kaolinite; Chlor = chlorite; Qtz = quartz; Alk $\mathrm{F}=$ alkali feld spars; Plag $=$ plagioclase $;$ Calc $=$ calcite Dolo $=$ dolomite.

We infer that Ordovician-Silurian limestones and dolostones of Ellesmere and Devon islands and, to a lesser extent, those of Bylot Island are the ultimate source of most of the calcite and dolomite found in Baffin Bay sediments and form an important end-member. Another possible source is Mesozoic-Cenozoic limestones and calcareous shales of the submerged coastal strata of both Baffin Island (MacLean and Falconer, 1979) and western Greenland (Johnson et al., 1975).

A second end-member is a quartzarenite source that yields the observed quartzarenite rock fragments, well-rounded quartz grains, quartz grains having surface stains of iron oxide, and quartz grains having overgrowths on a rounded core. The source of this quartzarenite is probably a thick sequence of Proterozoic quartzarenites on northern Greenland, Ellesmere Island, and northern Baffin Island (Dawes et al., 1982). Piston-core studies (Facies B in Aksu, 1981) allowed lithotype B horizons, enriched in quartzarenite debris, to be mapped throughout Baffin Bay. On the basis of this mapping, these reddish horizons are re- stricted to the western central part of Baffin Bay, just south of the mouth of Lancaster Sound. For this reason, Aksu (1981) concluded that the quartzarenite (plus red bed) source was in the Borden Basin or the Fury and Hecla Basin (Fig. 1), not in northern Greenland (Thule Basin). However, this conclusion does not preclude derivation of quartzarenite debris from the Thule Basin for deposits below piston-core depths-down to depths of about 550 mbsf.

There seems to be a clear association of quartzarenite detritus and colorless, often well-rounded, garnets (e.g., Sample $105-645 \mathrm{~F}-3 \mathrm{H}-05,70-72 \mathrm{~cm}$ ). Similar garnets were observed in quartzarenite clasts. Colorless garnets in surface sediments from Kane Basin at the northern end of Greenland (Kravitz, 1976) were interpreted as being derived from the Humboldt Glacier, just east of Proterozoic quartzarenite outcrops of the Thule Basin (Dawes et al., 1982). We do not know if quartzarenites of northern Baffin Island also are associated with a source for colorless garnets. 
Table 6. Mean mineralogy of $<2-\mu \mathrm{m}$-size fractions at Site 645 , all species total $100 \%$.

\begin{tabular}{lrrrrrrrrrr}
\hline \multicolumn{1}{c}{ Facies } & Smect $^{1}$ & Illite & Kaol & Chlor & Qtz & Alk F & Plag & Calc & Dolo & Pyrite \\
\hline Facies 1: Lithotype A & 4.0 & 12.4 & 7.6 & 2.0 & 19.4 & 5.3 & 8.4 & 8.0 & 32.9 & 0.2 \\
Facies 1: Lithotype B & 6.4 & 17.4 & 16.6 & 5.2 & 25.3 & 4.3 & 8.3 & 1.7 & 15.3 & 0.0 \\
Facies 1: Lithotype C & 5.5 & 16.6 & 9.7 & 2.9 & 24.1 & 6.7 & 12.5 & 2.3 & 19.1 & 0.3 \\
Facies 2 & 15.9 & 24.4 & 13.4 & 5.0 & 11.8 & 6.0 & 19.2 & 1.8 & 3.2 & 0.0 \\
Facies 3 & 5.7 & 15.8 & 13.2 & 4.9 & 16.0 & 5.0 & 8.5 & 4.5 & 27.0 & 0.0 \\
\hline
\end{tabular}

${ }^{1}$ Smect $=$ smectite; Kaol = kaolinite; Chlor = chlorite; Qtz = quartz; Alk F = alkali feldspars; Plag = plagioclase; Calc $=$ calcite; Dolo $=$ dolomite.

Red sandstones, siltstones and shales, and probably iron oxide clasts represent a third end-member. These may be derived from Precambrian sequences at the northern end of Baffin Bay, which locally contain iron formations (Dawes and Frisch, 1981). An alternate source for these red lithic clasts is Mesozoic red beds of western Greenland or the Bylot Island area (Fig. 1).

The last distinct end-member is a poorly lithified silty mudstone source for the abundant mudstone clasts and detrital micas of Facies 5, lithologic Subunit IIIA, and the lower part of lithologic Unit II (Sample 105-645B-27X-02, 48-53 cm, lithotype D). The presence of diatoms, spicules, and minor radiolarians in four samples suggests a Cretaceous or Paleogene age for this sedimentary source.

Many of the common light and heavy minerals in the Pliocene-Pleistocene section may be derived from various igneous and high-grade metamorphic source rocks of the Greenland and Arctic Island Precambrian shield (quartz, feldspar, minor schists, hornblende, pyroxenes, and pink garnets). The olivine that is essentially restricted to Facies 4 probably was derived from mafic volcanics of the Disko Island or Cape Dyer areas.

\section{Provenance of Clay Minerals}

In high latitudes, clay minerals of $<2 \mu \mathrm{m}$ size are mostly products of attrition rather than chemical weathering. In Baffin Bay sediments, illite and chlorite primarily, were derived from low-grade metamorphic rocks on Baffin Island and Greenland. However, these minerals may have been contributed from the Mesozoic-Cenozoic sedimentary successions of the Canadian Arctic Archipelago (Miall, 1986), the submerged and locally outcropping strata beneath the Baffin Island shelf (MacLean and Falconer, 1979), and the Cretaceous strata around Disko Island and Pond Inlet. We are not aware of any published body of clay-mineral data from these Mesozoic-Cenozoic sequences.

Possible sources for kaolinite are the Cretaceous-Tertiary fluviatile and deltaic sediments of the Disko Island area in western Greenland, the inferred Mesozoic and Cenozoic sedimentary rocks of the submerged coastal plain (Piper and Slatt, 1977; MacLean and Falconer, 1979), and to a lesser extent, the Mesozoic and Cenozoic rocks of Bylot Island and the Sverdrup Basin. Smectites probably were derived almost entirely from the same Mesozoic-Cenozoic shales, but very small amounts also may have been supplied from basic volcanic, intrusive, and metamorphic rocks. The proposed derivation of kaolinite and smectite from Cretaceous-Tertiary sediments is supported by the common occurrence of Cretaceous and Paleogene reworked palynomorphs in upper Pliocene and Pleistocene sediments at Site 645 (de Vernal and Mudie, this volume).

\section{Provenance of Facies 1}

\section{Lithotype A}

The petrology of the gravel fraction and the identified mineral assemblages indicate that the predominant source for lithotype A is carbonate rocks. The minor occurrence of other min- eral assemblages besides carbonates presumably indicates varying amounts of mixing with other sources. Because of the general absence of carbonate outcrops along the coastal area of Baffin Island and Greenland, we attribute the source of the carbonate debris in the unconsolidated sediments of Baffin Bay mainly to tranport by icebergs calved from glaciers eroding the Paleozoic carbonates of the Canadian Arctic Islands and northern Greenland (Marlowe, 1966; Grant, 1971; Aksu and Piper, 1987), specifically Ordovician-Silurian limestones and dolostones of Ellesmere, Devon, and Bylot islands, Greenland, and the Brodeur and Borden peninsulas of Baffin Island. Some dolostone clasts may have come from thick Proterozoic sections of the Thule and Borden basins (Jackson and Iannelli, 1981; Dawes et al., 1982), the same areas that contributed the rounded quartz grains found in this lithotype.

In addition to the Paleozoic and Proterozoic sources, minor older Precambrian and younger post-Paleozoic sources contributed the observed metamorphic mineral assemblages and reworked Mesozoic-Cenozoic clay minerals and palynomorphs, respectively.

\section{Lithotype B}

Palynomorphs from bulk piston-core samples (Aksu, 1981) suggest that an important part of the source terrane is of Mesozoic and Cenozoic age, probably the Mesozoic-Cenozoic siliciclastics of Disko and Bylot islands, Cape Dyer, Sverdrup Basin, and submerged equivalents on the adjacent continental shelves. Sedimentary rock fragments are common and varied (Tables 1 and 2). The relatively abundant kaolinite and smectite presumably were derived from shales of this age; kaolinite was reported from Upper Cretaceous to Paleogene rocks of the Sverdrup Basin (Riediger and Bustin, 1987). In contrast, metamorphic minerals, including most illite and all chlorite, probably were derived from the shield rocks of Baffin Island and Greenland. In some samples, carbonate rock fragments are also abundant, which suggests mixing of the detritus from siliciclastic sources with sediment from carbonate sources, such as those for lithotype A. We infer that this mixing was the result of a slow dropping of detritus at the depositional site from icebergs carrying sediment from the range of source areas mentioned above.

A second distinctive source is required for the quartzarenite clasts and hematite-stained, well-rounded quartz grains. The most attractive source is the Proterozoic siliciclastics of the Thule area of northwest Greenland, eastern Ellesmere Island, northeast Bylot Island, northern Brodeur Peninsula and the eastern Arctic Islands (Jackson and Iannelli, 1981; Dawes et al., 1982).

The distribution pattern of the mineral assemblages in this lithotype in piston cores (Aksu, 1981) favors a major northwestern source, possibly including Proterozoic, Mesozoic, and Cenozoic siliciclastics of Bylot Island, the adjacent shelf of northeastern Baffin Island, and the margins of Lancaster Sound (Devon Island and Borden Peninsula of Baffin Island). A minor contribution may have come from fluvial-deltaic sediments of the Disko Island area. The observed trends eliminate the possi- 
bility of Thule and Ellesmere Island Proterozoic and Cape Dyer Mesozoic and Cenozoic sediments as potential sources (Aksu, 1981), at least to depths that have been sampled by piston cores. Most detritus from the northwestern source was transported as debris in icebergs that entered Baffin Bay through Lancaster and Jones sounds.

\section{Lithotype $C$}

The sediments in this lithotype are polycyclic and composed of lower-order associations of different sources. In piston cores from the Greenland slope, the presence of abundant basaltic rocks associated with olivine indicates a major contribution from the Tertiary basaltic province of the Disko Island area. This volcanic influx is felt only weakly at Site 645 (Table 1), but volcanic fragments are more common than in lithotypes A or B.

Drab and red siliciclastic rock fragments and the significant amount of smectite and kaolinite (Table 5) suggest substantial influx from Mesozoic and Cenozoic sediments in coastal outcrops beneath the continental shelves of Baffin Island (Bylot Island area) or western Greenland (Disko Island area). High percentages of metamorphic minerals, especially clinopyroxene and hornblende, and metamorphic rock fragments in the gravel fraction (Aksu and Piper, 1987; Korstgaard and Nielsen, this volume) favor a major influx from the metamorphic complex of the Greenland/Arctic Islands shield. Carbonate minerals and rock fragments in this lithotype probably were derived from the same carbonate sources identified for lithotypes A and B. We infer that transport of detritus found in this lithotype to Site 645 was by ice rafting, although the possibility exists that some lithotype $\mathrm{C}$ beds could be debrites. The debrite cored by Hiscott and Aksu during Hudson cruise (87033) is lithologically similar to the heterolithic lithotype C.

\section{Lithotype $D$}

This lithotype is distinct from the other three in that carbonate sources are minor and are mainly dolostones. These dolostones may either be of Paleozoic age (lithotypes A, B, and C) or part of thick Proterozoic sections of the Thule Basin or the Borden Basin (Jackson and Iannelli, 1981; Dawes et al., 1982). Most other components probably have their ultimate sources in the Precambrian shield terranes that encircle Baffin Bay, particularly the relatively abundant pyroxenes (Table 3 ). Noncarbonate sedimentary clasts are varied (Sample 105-645B-22X-01, 118-123 $\mathrm{cm}$, Table 2), indicating a substantial amount of mixing of detritus from multiple sources.

One sample (105-645B-27X-02, 48-53 cm) is dominated by diatomaceous mudstone clasts such as those found in abundance in Facies 5. These clasts probably were derived from relatively unlithified Cretaceous-Tertiary sediments beneath the shelves of Baffin Island (MacLean et al., 1981) or western Greenland (Rolle, 1985). Reworked Cretaceous and Paleogene palynomorphs also are abundant in lithotype D (i.e., Unit II) samples (de Vernal and Mudie, this volume).

\section{Provenance of Facies 2}

This facies has a relatively small but significant contribution from carbonate sources (Table 4). The fine grain size of this facies results in low abundances of sedimentary rock fragments (Table 1), but Sample 105-645C-3H-04, 39-41 cm, having the most sedimentary clasts, indicates contributions from both redand drab-colored sedimentary source rocks (Table 2). Fine grain size is also the reason for the high abundance of feldspar (Tables 1 and 4).

Several components of both the light and heavy fractions indicate contribution from a shield terrane of hornblende-bearing quartzo-feldspathic gneisses and plutonic rocks. Illite and chlo- rite probably come mainly from the same shield source, whereas abundant smectite and kaolinite (Table 5) indicate contribution from a source in Mesozoic or younger sediments.

\section{Provenance of Facies 3}

The mineralogy of this facies essentially resembles that of lithotype A of Facies 1, although textures and sedimentary structures are quite different. There are not enough samples to modify our interpretation of source areas for lithotype A, and the comments given above for this lithotype apply equally to Facies 3.

\section{Provenance of Facies 4}

The silty fine sands of Facies 4 contain enough rounded quartz and sedimentary rock fragments to infer an important sedimentary source. Glauconite is widely dispersed in all samples and may have been derived from an older sedimentary source. One sample (105-645D-2R-04, 36-41 cm) contains many poorly lithified silty mudstone clasts with diatoms (like Facies 5). Basaltic rock fragments are present, along with significant amounts of detrital olivine, a heavy mineral only rarely encountered in other facies. These constituents suggest derivation from the western coast of Greenland, where thick Mesozoic and Tertiary sequences and mafic volcanics are now exposed in the vicinity of Disko Island and offshore. Several of the MesozoicTertiary units contain glauconite (Rolle, 1985). Rare dolomite grains may have been contributed by ice-rafting from the northern end of Baffin Bay, but this was a minor source.

\section{Provenance of Facies 5}

Without exception, the samples from Facies 5 indicate derivation in major part from a sequence of poorly lithified silty and sandy mudstones, probably Mesozoic-Tertiary clastics on land and beneath the continental shelves of west Greenland and northeastern Baffin Island (Bylot Island area). Ubiquitous detrital micas probably also come from this sedimentary source. Hornblende that dominates the heavy mineral suite occurs within silty and sandy mudstone clasts and thus may also be recycled.

The detritus in Facies 5 was transported to the site either as the suspended load and bedload of bottom currents (Hiscott et al., this volume), or through ice-rafting. Rare quartzarenite and dolostone clasts strongly suggest a minor ice-rafted contribution from rocks found at the northern end of Baffin Bay or around Lancaster Sound.

\section{POINT SOURCES}

General support exists for the hypothesis that the facies at Site 645 represent some degree of mixing of sediments derived from several sources, or at least several rock types in one area (primary associations). In a few cases, however, rock fragments or heavy-mineral species require derivation from a unique source rock, perhaps contributed by a single glacier. The reconnaissance nature of this study does not allow specification of the frequency with which unique sources were able to dominate sedimentation locally. Three examples are given as follows:

1. Sample $105-645 \mathrm{~B}-1 \mathrm{X}-01,100-102 \mathrm{~cm}$, of lithotype A contains $25 \%$ aegirine in its nonopaque heavy-mineral portion, a pyroxene that is essentially absent in all other samples. Aegirine is associated particularly with alkaline igneous rocks, such as nepheline syenite, and probably has limited distribution. Its presence in abundance in only one sample suggests a point source that operated for a short time only. Potential source rocks include the extensive Proterozoic Gardar alkaline complexes of southern Greenland (Emeleus and Upton, 1976; Bailey 
et al., 1981) and younger alkaline rocks in the same area that range in age into the Cretaceous (Larsen et al., 1983).

2. Sample $105-645 \mathrm{~F}-3 \mathrm{H}-05,70-72 \mathrm{~cm}$, of lithotype B bears a strong signature of the Proterozoic quartzarenite end-member (Tables 1 and 3 ) and also contains a remarkable concentration of rounded, colorless garnets in its heavy-mineral suite. This rounding and the observation of garnets within quartzarenite clasts suggest that the garnets were derived from these older sediments and that the rounding may be an inherited feature. The high proportion of rounded garnets in this particular sample may reflect erosion by a single ice tongue of a particularly garnet-rich horizon within the quartzarenite sequence (?paleoplacer), and the fortuitous dropping of debris from an iceberg calved from that ice tongue at Site 645 .

3. Sample $105-645 \mathrm{C}-3 \mathrm{H}-04,39-41 \mathrm{~cm}$, of Facies 2 contains common glauconite peloids and sedimentary rock fragments characterized by glauconite peloids (Table 2). Such an abundance of glauconite is anomalous and suggests derivation from a group of beds having a particularly glauconite-rich horizon, perhaps in Mesozoic-Tertiary strata of the Disko Island area (Rolle, 1985).

\section{DISCUSSION}

From the provenance interpretations presented, one can see clearly that source rocks in different parts of Baffin Bay were tapped at different times during the Pliocene-Pleistocene. During the early Pliocene, represented at Site 645 by Facies 5 , the predominant source was poorly lithified Cretaceous-Tertiary sediments. Modern outcrops of potential source rocks are found in the Disko Island area of west Greenland and the Bylot Island area of Baffin Island. However, offshore extensions of these outcrop belts onto adjacent shelves have considerable areal extent (MacLean et al., 1981; Rolle, 1985) and may be the ultimate source areas for detritus in lower Pliocene deposits. Transverse troughs cutting the Baffin Bay shelves have been excavated locally to depths of several hundred meters into these Cretaceous-Tertiary sequences.

Although the locations of the eroded Cretaceous-Tertiary sediments cannot be specified accurately, known geology favors the shelves on the eastern and western sides of Baffin Bay, with the eastern (Greenland) source apparently having the greater volume. If the influx of lithic fragments from these sources was prompted by glacial erosion and calving of sediment-laden icebergs, then it is conceivable that the first major Greenland ice sheet reached the Baffin Bay coast in the general area of modern Disko Island, not at the northern end of Greenland. Ice sheets apparently did not develop to any significant extent at this time on the Canadian Arctic Islands, perhaps because of climate moderation by encircling water bodies. Icebergs from western Greenland also are required to account for the olivine and volcanic grains in Facies 4, which is of late Pliocene age.

Carbonate rock fragments are uncommon below the top of lithologic Unit II, but the dolomite grains that are present below this level show no obvious signs of corrosion. We believe that carbonate detritus is uncommon below Unit I because glaciers did not grow to sufficient size on Ellesmere and Devon islands and on northern Greenland to provide significant detritus. At the base of lithologic Unit I, glaciers at the northern end of Baffin Bay finally reached the coastline, eventually filling and blocking the channels between the Arctic Islands. These glaciers calved icebergs that contributed detritus from (1) Proterozoic siliciclastics, including red beds and quartzarenites; (2) Paleozoic limestones and dolostones; and (3) Mesozoic drab and red siliciclastics.

Within lithologic Subunit IA, alternations in detrital mineralogy are attributed directly to alternations between source areas. Carbonate sources of Ellesmere and Devon islands and north- ern Greenland predominated during deposition of lithotype A and Facies 3 (Fig. 6A), and mixed carbonate, sedimentary, and crystalline shield sources predominated during deposition of lithotypes B and C, and Facies 2 (Fig. 6B and 6C). A Proterozoic sedimentary source was most important for lithotype B (Fig. 6B), whereas clay minerals in all samples analyzed show a contribution from Mesozoic and Cenozoic sediments.

A fundamental question that concerned all shipboard scientists is what causes mineralogical and textural cycles in Subunit IA? Armed with a preliminary assessment of the geographic distribution of sources (Fig. 6), we attempt below to explain the cyclicity.

Facies 2 is poorest in ice-rafted sand and gravel and on the basis of oxygen-isotope data gathered from foraminifers in piston-core samples (Aksu, 1985) and Site 645 samples (data in Hillaire-Marcel et al., this volume) is commonly characterized by relatively heavy oxygen-isotopic composition. Sedimentation was dominated by hemipelagic and resedimentation processes during deposition of this facies. The relatively heavy oxygenisotopic composition is believed to result from minimal melting of glacial ice, consistent with the lack of significant ice-rafted detritus. Little melting of ice and insignificant calving of icebergs (or calving but no melting of icebergs in the bay) suggest cold conditions with buildup of glacial ice and predominance of dry-based glaciers.

The upward transition from Facies 2 (plus locally Facies 3) into Facies 1 in most cases is accompanied by a decrease in $\delta^{18} \mathrm{O}$ (Aksu, 1985; data in Hillaire-Marcel et al., this volume), believed to indicate an increase in the local melting of glacial ice, either at the bases of glaciers or as a consequence of melting of icebergs calved from the glaciers. Iceberg melting would account for the dramatic increase in sand and gravel in Facies 1 relative to Facies 2. Examination of samples from lithotype A of Facies 1 indicates an unexpected high concentration of planktonic foraminifer tests, which suggests enhanced surface productivity, perhaps as a result of warmer water temperatures. All of the above features suggest a warming trend, both on land to account for accelerated glacial advance and iceberg calving, and in the bay to account for enhanced local melting of the icebergs.

The sources that provided the first ice-rafted debris during warming (lithotype B) are closest to the open waters of Baffin Bay (Fig. 6B), and probably were at sites where warmer climate accelerated the rate of iceberg calving. As the warming trend continued, inland and highland glaciers began to move at higher rates, and carbonate rocks eroded from these areas began to predominate in the sedimentary record in the bay (lithotype A, Fig. 6A). We believe that sediment accumulation rates were highest at this time.

Sediment yields began to decrease as local temperatures again began to decrease, freezing glaciers to their beds. Decreasing surface-water temperatures simultaneously led to a decrease in the melting rate of icebergs, and augmented escape of ice-borne debris from Baffin Bay into the Labrador Sea. This cooling period is reflected in a gradual transition from Facies 1 into Facies 2 and an inferred decrease in sediment accumulation rate suggested by an increase in burrow density in the sediment.

The main features of the model proposed here for cyclicity in Subunit IA are summarized in Figure 7. The driving force for this cyclicity is believed to be fluctuations in local climate, perhaps brought about by incursions of relatively warm water masses from the North Atlantic Ocean. Locally, the primary effect of warming is landward expansion of wet-based conditions in glaciers surrounding the bay, increased melting of glaciers, and increased melting of sediment-laden icebergs.

A possible, although speculative, explanation for climatic warming after a period of ice buildup is that expanding ice sheets at the northern end of Baffin Bay eventually fill and block channels connecting the Arctic Ocean with Baffin Bay, al- 

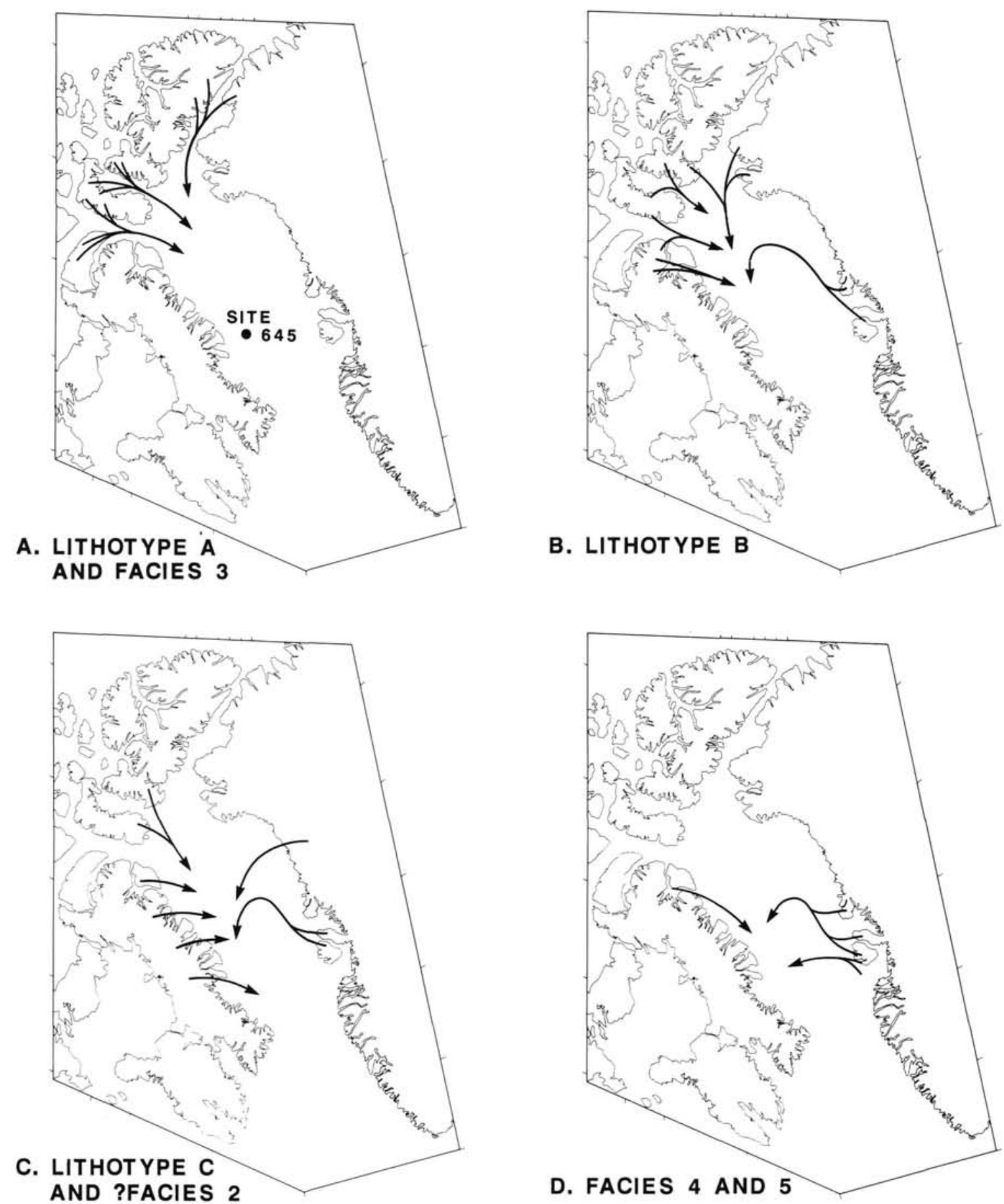

Figure 6. Schematic representation of the transport paths of the most characteristic detrital populations found in the various lithotypes and facies at Site 645. In most cases, other sources also contributed variable quantities of detritus, but are not responsible for the distinctive signature of the facies or lithotype. The tails of the arrows are situated on appropriate bedrock determined from petrographic and X-ray analysis (for bedrock character, see Fig. 1), although adjacent shelves may also have acted as sources, particularly for Facies 5. Precise paths to the drill site are uncertain and are styled on the known drift paths of modern icebergs (Hiscott et al., this volume). Lithotype D samples most bedrock types and thus is not shown separately here.

lowing the influence of warmer North Atlantic water masses on climate and water temperatures in Baffin Bay to increase.

\section{ACKNOWLEDGMENTS}

A. Aksu and R. Hiscott thank the Natural Sciences and Engineering Research Council of Canada, who supported this research under the
Collaborative Special Projects category. O. Nielsen received financial support from the Danish Natural Science Research Council. Drafting and photography were performed by Larry Nolan, David MacNeil, Wilf Marsh, and Elizabeth Hearn. Samples for petrographic analysis were prepared by Dino Nardini. X-radiography of cores was supervised by Rusty Lotti at the ODP East Coast Repository, Lamont-Doherty Geological Observatory. 
RATE OF ACCUMULATION

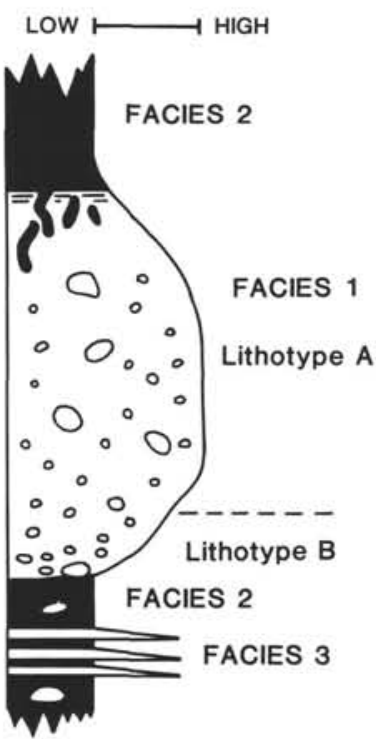

$\delta^{18} \mathrm{O}$ FROM PISTON CORES

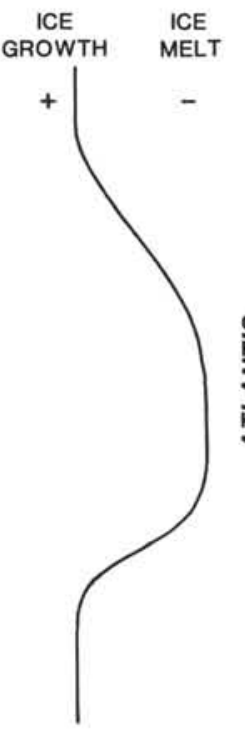

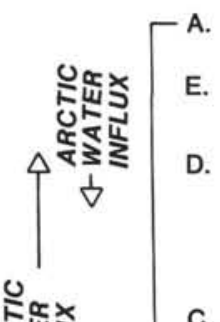

C. Massive calving from wet-based hinterland glaciers, melting of icebergs in the bay, carbonate sources tapped.

B. Calving from coastal glaciers around Lancaster Sound, siliciclastic source.

A. Cold, ice-blocked channels, exclusion of Arctic water.

Figure 7. Model of the cyclic sampling of bedrock from different areas around Baffin Bay in the context of an oscillating ice margin and associated meltwater pulses. We believe that a critical factor in triggering deposition of gravel-bearing Facies 1 is the incursion of relatively warm Atlantic surface water into Baffin Bay.

\section{REFERENCES}

Aksu, A. E., 1981. Late Quaternary stratigraphy, paleoenvironment and sedimentation history of Baffin Bay and Davis Strait [Ph.D. dissert.]. Dalhousie University, Halifax, Canada.

1985. Climatic and oceanographic changes over the past 400,000 years: evidence from deep-sea cores on Baffin Bay and Davis Strait. In Andrews, J. T. (Ed.), Quaternary Environments: Eastern Canadian Arctic, Baffin Bay and Western Greenland: London (Allen and Unwin), 181-209.

Aksu, A. E., and Piper, D.J.W., 1987. Late Quaternary sedimentation in Baffin Bay. Can. J. Earth Sci., 24:1833-1846.

Bailey, J. C., Larsen, L. M., and Sørensen, H. (Eds.), 1981. The Ilimaussaq Intrusion, South Greenland. Geol. Surv. Greenland Rept., 103.

Biscaye, P. E., 1965. Mineralogy and sedimentation of Recent deep-sea clays in the Atlantic Ocean and adjacent seas and oceans. Geol. Soc. Am. Bull., 76:803-832.

Blatt, H., 1982. Sedimentary Petrology: San Francisco (W. H. Freeman and Company).

Brett, C. P., and Zarudzki, E.F.K., 1979. Project Weasmare, a shallow marine geophysical survey on the west Greenland continental shelf. Geol. Surv. Greenland Rept., 87.

Brindley, G. W., and Brown, G., 1980. Crystal structures and clay minerals and their X-ray identification. Mineral. Soc. Mono., 5.

Callahan, J., 1987. A nontoxic heavy liquid and inexpensive filters for separation of mineral grains. J. Sediment. Petrol., 57:765-766.

Clarke, D. B., and Upton, G. J., 1971. Tertiary basalts of Baffin Island: field relations and tectonic setting. Can. J. Earth Sci., 8:248-258.

Cook, H. E., Johnson, P. D., Matti, J. C., and Zemmels, I., 1975. Methods of sample preparation and X-ray diffraction data analysis, X-ray Mineralogy Laboratory, Deep Sea Drilling Project, University of California, Riverside. In Hayes, D. A., Frakes, L. A., et al., Init. Repts. DSDP, 28: Washington (U.S. Govt. Printing Office), 9991008.

Dawes, P. R., and Frisch, T., 1981. Geological reconnaissance of the Greenland Shield in Melville Bugt, northwest Greenland. Geol. Surv. Greenland Rept., 105:18-26.

Dawes, P. R., Frisch, T., and Christie, R. L., 1982. The Proterozoic Thule Basin of Greenland and Ellesmere Island: importance to the Nares Strait debate. Meddelelser om Grónland, Geosci., 8:89-104.

Douglas, R.J.W. (Ed.), 1970. Geology and Economic Minerals of Canada: Ottawa (Geol. Surv. of Canada).
Emeleus, C. H., and Upton, B.G.J., 1976. The Gardar period in southern Greenland. In Escher, A., and Watt, W. S. (Eds.), Geology of Greenland: Copenhagen (Geol. Surv. of Greenland), 152-181.

Escher, A. (compiler), 1970. Tectonic/Geological Map of Greenland $(1: 2,500,000)$ : Copenhagen (Geol. Surv. of Greenland).

Folk, R. L, 1955. Student operator error in determination of roundness, sphericity, and grain size. J. Sediment. Petrol., 25:297-301.

Frisch, T., and Dawes, P. R., 1982. The Precambrian shield of northernmost Baffin Bay: correlation across Nares Strait. Meddelelser om Grónland, Geosci., 8:79-88.

Galehouse, J. S., 1969. Counting grain mounts: number percentage vs. number frequency. J. Sediment. Petrol., 39:812-815.

Grant, A. C., 1971. Distributional trends in the recent marine sediments of northern Baffin Bay. Maritime Sediment., 7:41-63.

Henderson, G., 1973. The geophysical setting of the West Greenland Basin in Baffin Bay region. Geol. Surv. Can. Pap., 71-23:521-544.

Henderson, G., Schiener, E. J., Risum, J. B., and Croxton, C. A., 1981. The West Greenland Basin. In Kerr, J. W., and Fergusson, A. J. (Eds.), Geology of the North Atlantic Borderlands. Can. Soc. Petrol. Geol. Mem., 7:399-428.

Jackson, G. D., and Iannelli, T. R., 1981. Rift-related cyclic sedimentation in the Neohelikian Borden Basin, northern Baffin Island. In Campbell, F.H.A. (Ed.), Proterozoic Basins of Canada. Geol. Surv. Can. Pap., 81-10:269-302.

Johns, W. D., Grim, R. E., and Bradley, W. F., 1954. Quantitative estimation of clay minerals by diffraction methods. J. Sediment. Petrol., 24:242-251.

Johnson, G. L., McMillan, N. J., Rasmussen, M., Campsie, J., and Dittmer, F., 1975. Sedimentary rocks dredged from the southwest Greenland continental margin. In Yorath, C. J., Parker, E. R., and Glass, D. J. (Eds.), Canada's Continental Margins and Offshore Petroleum Exploration. Can. Soc. Petrol. Geol. Mem., 4:391-409.

Kerr, J. Wm., 1976. Stratigraphy of central and eastern Ellesmere Island, Arctic Canada, Part III. Geol. Surv. Can. Bull., 260:1-55.

Kravitz, J. N., 1976. Textural and mineralogical characteristics of the surficial sediments of Kane Basin. J. Sediment. Petrol., 46:710-725.

Larsen, L. M., Rex, D. C., and Secher, K., 1983. The age of carbonatites, kimberlites and lamprophyres from southern west Greenland: recurrent alkaline magmatism during 2500 million years. Lithos, 16 : 215-221.

MacLean, B., Jansa, L. F., Falconer, R.K.H., and Srivastava, S. P., 1977. Ordovician strata on the southeastern Baffin Island shelf revealed by shallow drilling. Can. J. Earth Sci., 14:1925-1939. 
MacLean, B., and Falconer, R.K.H., 1979. Geological/geophysical studies in Baffin Bay, and Scott Inlet-Buchan Gulf and Cape DyerCumberland Sound area of the Baffin Island shelf. Geol. Surv. Can. Pap., 79-1B:231-244.

MacLean, B., Falconer, R.K.H., and Levy, E. M., 1981. Geological, geophysical and chemical evidence for natural seepage of petroleum off the northeast coast of Baffin Island. Bull. Can. Soc. Petrol. Geol., 29:75-95.

Marlowe, J. I., 1966. Mineralogy as an indicator of long-term current fluctuations in Baffin Bay. Can. J. Earth Sci., 3:191-201.

Miall, A. D., 1986. The Eureka Sound Group (Upper Cretaceous-Oligocene), Canadian Arctic Islands. Bull. Can. Soc. Petrol. Geol., 34: 240-270.

Miall, A. D., Balkwill, H. R., and Hopkins, W. S., Jr., 1980. Cretaceous and Tertiary sediments of Eclipse Trough, Bylot Island area, Arctic Canada, and their regional setting. Geol. Surv. Can. Pap., 79-23.

Milner, H. B., 1962. Sedimentary Petrography, Vol. 2: Principles and Applications: London (Allen and Unwin).

Pettijohn, F. J., Potter, P. E., and Siever, R., 1973. Sand and Sandstone: New York (Springer-Verlag).

Piper, D.J.W., and Slatt, R. M., 1977. Late Quaternary clay mineral distribution on the eastern continental margin of Canada. Geol. Soc. Am. Bull., 88:267-272.
Riediger, C. L., and Bustin, R. M., 1987. The Eureka Sound Formation, southern Ellesmere Island. Bull. Can. Soc. Petrol. Geol., 35: 123-142.

Rolle, F., 1985. Late Cretaceous-Tertiary sediments offshore central west Greenland: lithostratigraphy, sedimentary evolution, and petroleum potential. Can. J. Earth Sci., 22:1001-1019.

Schultz, L. G., 1964. Quantitative interpretation of mineralogical composition from X-ray and chemical data for the Pierre Shale. U.S. Geol. Surv. Prof. Pap., 391-C.

Srivastava, S. P., Arthur, M., et al., 1987. Proc. ODP, Init. Repts., 105: College Station, TX (Ocean Drilling Program).

Thorsteinsson, R., and Tozer, E. T., 1960. Summary accounts of structural history of the Canadian Arctic Archipelago since Precambrian time. Geol. Surv. Can. Pap., 60-7.

West, R. M., Dawson, M. R., Hickey, L. J., and Miall, A. D., 1981. Upper Cretaceous and Paleogene sedimentary rocks, eastern Canadian Arctic and related North Atlantic areas. In Kerr, J. W., and Fergusson, A. J. (Eds.), Geology of the North Atlantic Borderlands. Can. Soc. Petrol. Geol. Mem., 7:279-298.

Date of initial receipt: 20 July 1987

Date of acceptance: 18 November 1987

Ms 105B-117 

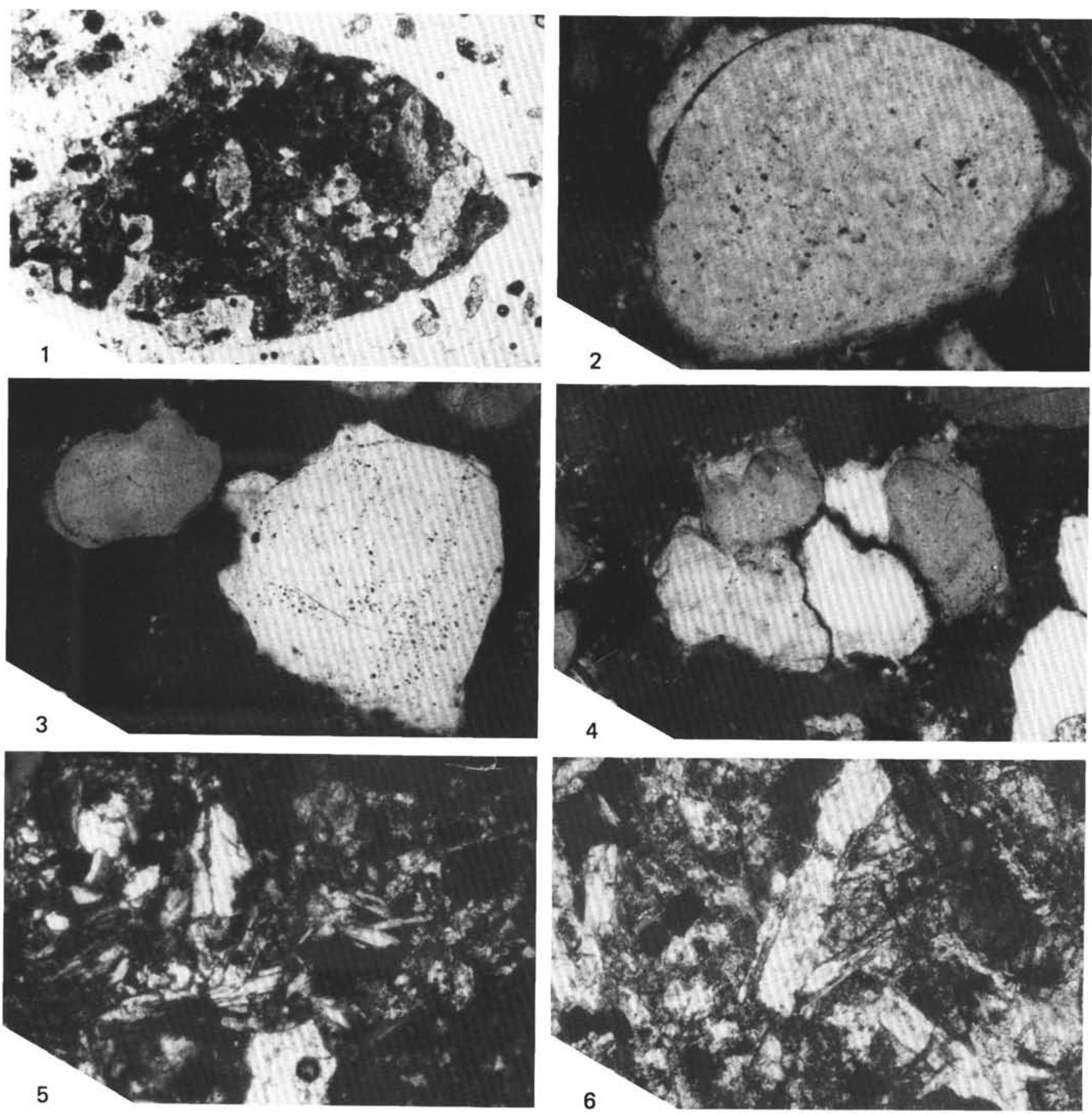

Plate 1. Photomicrographs of characteristic grain types in thin sections from Site 645. 1. Stained limestone clast having large echinoderm plates (Sample 105-645B-5X-03, 93-96 cm, plane-polarized light, field 3-mm wide). 2. Recycled quartz grain having round shape and relict attached overgrowths that formed part of the cement of the parent sandstone (Sample 105-645E-6R-01, 93-98 cm, crossed nicols, field 0.6-mm wide). 3. Two rounded, recycled quartz grains with relict overgrowths outside a faint primary grain boundary (Sample 105-645F-3H-05, 70-72 cm, crossed nicols, field 0.6-mm wide. 4. Quartzarenite sedimentary rock fragment (Sample 105-645F-3H-05, 70-72 cm, crossed nicols, field 0.4-mm wide). 5. Volcanic rock fragment containing olivine and plagioclase laths (Sample 105-645B-11X-01, 43-48 cm, crossed nicols, field 0.6-mm wide). 6. Volcanic rock fragment containing relict pyroxene and plagioclase laths (Sample 105-645B-13X-04, 46-51 cm, crossed nicols, field 0.6-mm wide). 

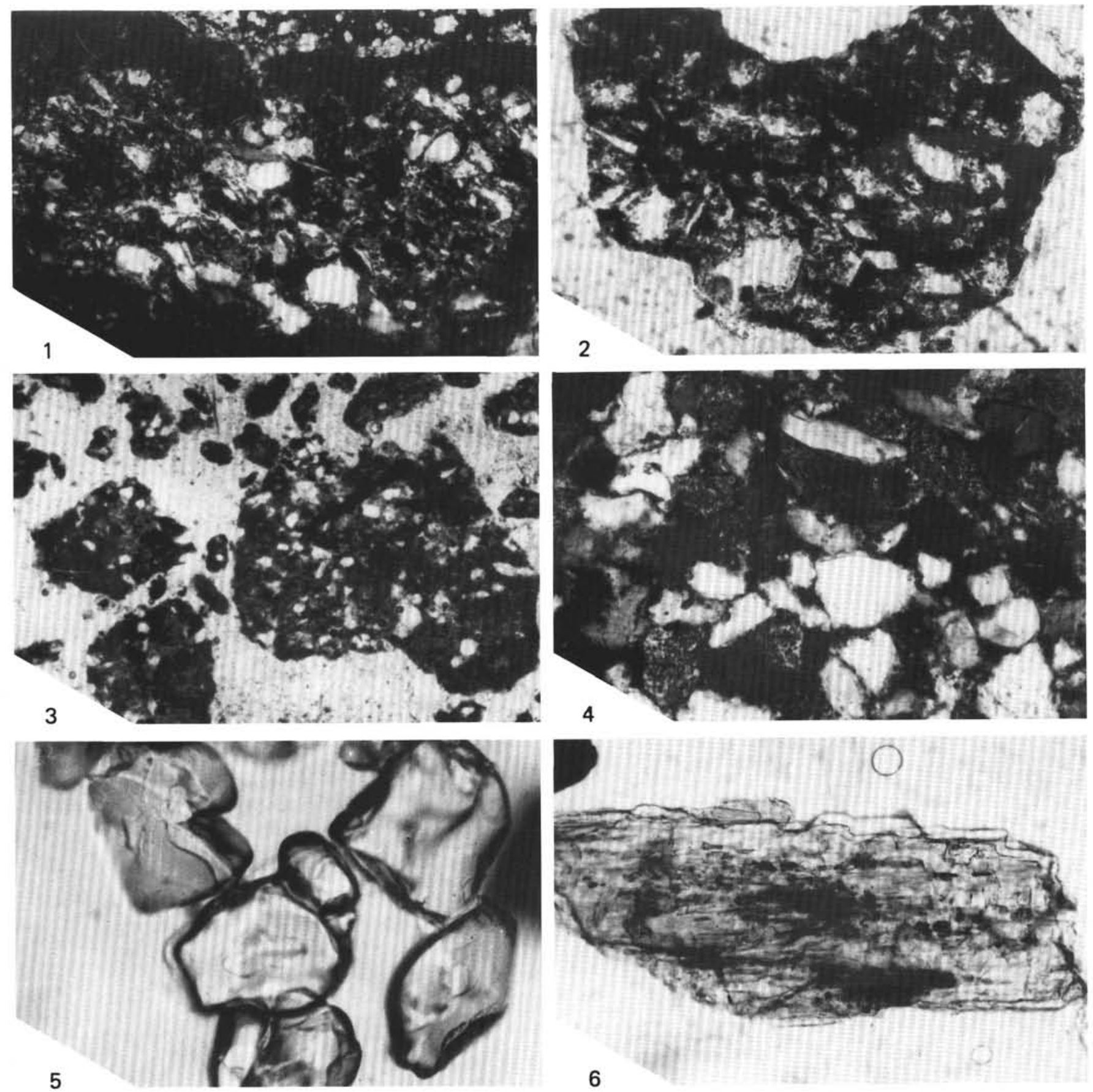

Plate 2. Photomicrographs of light and heavy grains from Site 645. 1. Metasedimentary rock fragment with muscovite and chlorite crystals aligned preferentially from above middle left to below middle right (Sample 105-645F-2H-01, 85-87 cm, crossed nicols, field 0.6-mm wide). 2. Red, hematitic sedimentary rock fragment (Sample 105-645B-1X-02, 120-122 cm, plane-polarized light, field 0.3-mm wide). 3. Abundant, brown, diatom-bearing mudstone clasts (Sample 105-645E-9R-06, 59-64 cm, plane-polarized light, field 0.3-mm wide). 4. Quartzose sandstone clast having about $20 \%$ glauconite pellets (speckled) (Sample 105-645C-3H-04, 39-41 cm, crossed nicols, field $0.6 \mathrm{~mm}$ wide). 5. Rounded, colorless garnets in a grain mount of heavy minerals (Sample 105-645F-3H-05, 70-72 cm, plane-polarized light, field $0.6 \mathrm{~mm}$ wide). 6. Aegirine grain having near-parallel extinction and inclusions (Sample 105-645B-1X-01, 100-102 cm, plane-polarized light, field $0.6 \mathrm{~mm}$ wide). 